\title{
Diglyme based electrolytes for sodium-ion
}

\section{batteries}

\author{
K. Westman, ${ }^{a}$ R. Dugas, ${ }^{c}$ P. Jankowski, ${ }^{\text {adg }}$ W. Wieczorek, ${ }^{d g}$ G. Gachot, ${ }^{\text {ef }}$ M. \\ Morcrette, ${ }^{\text {efg }}$ E. Irisarri, ${ }^{b}$ A. Ponrouch, ${ }^{b}$ M. R. Palacín, ${ }^{b g}$ J. M. Tarascon ${ }^{c g}$ and P. Johansson ${ }^{* a g}$ \\ a Department of Physics, Chalmers University of Technology, SE-412 96 Göteborg, \\ Sweden.
}

${ }^{b}$ Institut de Ciència de Materials de Barcelona (ICMAB-CSIC), Campus UAB, 08193 Bellaterra, Catalonia, Spain.

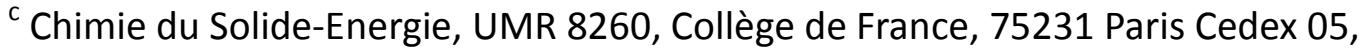
France.

${ }^{\mathrm{d}}$ Warsaw University of Technology, Faculty of Chemistry, 00-664, Warszawa, ul. Noakowskiego 3, Poland.

${ }^{\text {e }}$ Laboratoire de Réactivité et Chimie des Solides, CNRS UMR 7314, Université de Picardie Jules Verne, Rue Beaudelocque, 80039, Amiens, France.

${ }^{f}$ Réseau sur le Stockage Electrochimique de l'Energie (RS2E), FR CNRS 3459, France.

${ }^{g}$ ALISTORE European Research Institute (ALISTORE-ERI), FR CNRS 3104, France.

*patrik.johansson@chalmers.se 
Keywords: Batteries, electrolytes, stability, degradation, sodium-ion

Abstract

Sodium-ion batteries (SIBs) are currently being considered for large-scale energy storage. Optimisation of SIB electrolytes is, however, still largely lacking. Here we exhaustively evaluate $\mathrm{NaPF}_{6}$ in diglyme as an electrolyte of choice - both physico-chemical properties and extensive electrochemical tests including half as well as full cells.

Fundamentally, the ionic conductivity is found to be quite comparable to carbonate based electrolytes and obeying the fractional Walden rule with viscosity. We find Na metal to work well as a reference electrode and the electrochemical stability, evaluated potentiostatically for various electrodes and corroborated by DFT calculations, to be satisfactory in the entire voltage range of 0-4.4 V. Galvanostatic cycling at C/10 of half and full cells using $\mathrm{Na}_{3} \mathrm{~V}_{2}\left(\mathrm{PO}_{4}\right)_{3}$ (NVP) or $\mathrm{Na}_{3} \mathrm{~V}_{2}\left(\mathrm{PO}_{4}\right)_{2} \mathrm{~F}_{3}$ (NVPF) as cathodes and hard carbon $(\mathrm{HC})$ as anodes indicate rapid capacity fading in cells with $\mathrm{HC}$ anodes, possibly originating in a lack of a stable SEI or by trapping of sodium. Aiming to understand this capacity fade further, we conducted a GC/MS analysis to determine electrolyte reduction products and to propose reduction pathways, concluding that oligomer and/or alkoxide formation is possible. Overall, the promising results should warrant further investigations of diglyme based electrolytes for modern SIB development, albeit avoiding HC anodes. 


\section{Introduction}

Striving to minimise greenhouse gas emissions, electrification of our society is a key solution. Rechargeable batteries are predicted to play a major role for storing energy in mobile applications and large-scale systems, such as load balancing of intermittent renewable energy sources ${ }^{1}$. Current state-of-the-art lithium-ion batteries (LIBs) were commercialised in the early 1990's ${ }^{2}$, but stakeholders for Li are not limited to battery manufacturers and Li production and resources are centred to a few regions of the world, making supply and geopolitical factors important aspects to include in a cost/risk-assessment for LIB production ${ }^{3,4}$. Thus, there exists a motivation for development of alternative rechargeable battery technologies. Sodium-ion batteries (SIBS) are seen as an especially promising alternative to LIBs due to their very similar chemistry and not the least as $\mathrm{Na}$ is approximately three orders of magnitude more abundant in the Earth's crust and with reserves abundant nearly all over the globe ${ }^{5,6}$.

As for now, most full SIBs reported have cathodes made of either layered oxides or a polyanionic framework such as $\mathrm{Na}_{3} \mathrm{~V}_{2}\left(\mathrm{PO}_{4}\right)_{3}(\mathrm{NVP})$ or $\mathrm{Na}_{3} \mathrm{~V}_{2}(\mathrm{PO} 4)_{2} \mathrm{~F}_{3}$ (NVPF), and hard carbon (HC) anodes ${ }^{7}$. There is a documented stable cycling performance at $284 \mathrm{Wh} \mathrm{kg}^{-1}$ based on the electrode materials ${ }^{8-11}$ and $267 \mathrm{Wh} \mathrm{kg}^{-1}$ for full cells, the lower figure for the latter due to the extra sodium needed to compensate for the initial irreversible loss of capacity, attributed to solid electrolyte interphase (SEI) formation and electrolyte decomposition ${ }^{7}$. A possible mitigation strategy is to add a Na source to the positive electrode, allowing for a reduced sodium consumption during the first charge/discharge cycle ${ }^{7}$.

Studies on electrolytes and the SEI formation are still scarce for SIBs ${ }^{5}$. Simply adopting LIB equivalent electrolyte compositions lead to SEIs less stable than for $\operatorname{LIBs}^{12}$, possibly due to a more pronounced dissolution of reduction products due to the lower Lewis acidity of $\mathrm{Na}{ }^{13}$. 
Also the higher redox potential of $\mathrm{Na}$ seems to hinder further reduction of primary reduction products, such as diethylene carbonate, into secondary reduction products, indicating that the SEI would have a different composition and different performance in terms of stability ${ }^{7,14}$. A recent study by lermakova et al. on the SEI formation on Li and $\mathrm{Na}$ indicates that SEIs formed on $\mathrm{Na}$ from carbonate based electrolytes are less stable as compared to the equivalent Li case ${ }^{12}$.

There is thus a need to continue widening the knowledge in "SEl engineering" for SIBs and to explore new electrolytes. Electrolytes using "glymes", [R-( $\left.\left(\mathrm{OCH}_{2} \mathrm{CH}_{2}\right)_{n}-\mathrm{OR}\right]$, as solvents, have only recently been studied for SIBs ${ }^{15-20}$ as well as very recently for Na-S batteries ${ }^{21}$. The glymes, also abbreviated "Gn"- G1 being monoglyme, G2 diglyme, etc., are stable and amphiphilic solvents with wide liquidus ranges ${ }^{22}$. Early work using Li metal anodes indicated glymes to cause a high surface roughness upon plating/stripping and therefore declared these solvents to be inappropriate ${ }^{23}$ and furthermore to have a low solubility of the LiPF 6 salt ${ }^{23,24}$. Tobishima et al. circumvented the solubility problem by mixing glymes and ethylene carbonate/methylethyl carbonate (EC/MEC) and systematically evaluated the physicochemical properties and Li cycling efficiency for $n=1-4$ and $R=M e^{24}$. The conductivities obtained were higher for the glyme based electrolytes than for the pure MEC based electrolytes. Recent work by Jache et al. exploited the chelating properties of glymes to reversibly intercalate $\mathrm{Na}$ into graphite as a complex ${ }^{15,25}$. Seh et al. studied plating/stripping of $\mathrm{Na}$ on $\mathrm{Cu}$ surfaces using different salt/diglyme combinations. They showed $1 \mathrm{M} \mathrm{NaPF}_{6}$ in diglyme to result in high reversibility, related to the formation of a stable SEI ${ }^{17}$. No study, however, has to the best of our knowledge been conducted on using glymes for full and "conventional" cells of SIBs. 
Here we report on the use of diglyme as an electrolyte solvent for SIBs comprising $\mathrm{NaPF}_{6}$ aS the electrolyte salt, NVPF or NVP based cathodes, and HC or NVP based anodes. The study aims both to in detail characterise the physico-chemical properties of the electrolytes, to evaluate the cycling stability of the cells made, and to decipher possible degradation mechanisms - all combined to assess the possible use of diglyme based electrolytes in SIBs. 


\section{Computational and experimental methods}

\subsection{Materials}

Electrodes were obtained by punching disks from NVPF and HC laminated on Al current collectors (CEA, Grenoble). The HC electrodes had a reasonably high active material loading of 5.0-5.2 $\mathrm{mg} \mathrm{cm}^{-2}$, while the loading of the NVPF electrodes was even higher: $5.2-12.4 \mathrm{mg}$ $\mathrm{cm}^{-2}$. The mass ratios, expressed as active material:Super $P$ Carbon $\left(C_{\mathrm{sp}}\right)$ :PVDF binder, were 90:5:5 and 92:4:4 for the NVPF and the HC electrodes, respectively. The balancing for full cells, in grams of active material, was 1:2.01 (HC:NVPF), 1:2.57 (HC:NVP), 3.2:1 (NVP:NVPF) and 2.3:1 (NVP:NVP). When needed, additional active material was introduced to modify the balancing of the cells. The electrodes were dried at $80^{\circ} \mathrm{C}$ under vacuum for $24 \mathrm{~h}$ in a Büchi oven before they were stored and further handled in an argon-filled glove box (M-Braun MB200-MOD). NVP was prepared by ball milling with 20 wt $\% C_{s p}$ and the powdered material directly used as an electrode. For Na-metal anodes, a stainless steel disk was thinly coated with $\mathrm{Na}$, ensuring that the metal covered the whole disk and that the surface was as flat as possible to avoid roughness-related effects.

Diethylene glycol dimethyl ether (diglyme/G2, 99.5\%, anhydrous, Sigma-Aldrich), ethylene carbonate (EC, 99\%, anhydrous, Sigma-Aldrich) and dimethyl carbonate (DMC, 99\%, anhydrous, Sigma-Aldrich) were all used as received. Single solvent electrolytes were prepared by direct mixing of an appropriate amount of $\mathrm{NaPF}_{6}$ (Stella Chemifa) to reach the desired salt concentration, defined as mole per $\mathrm{dm}^{3}$ of solvent. The mixed solvent electrolytes, $\mathrm{EC}_{50}: \mathrm{DMC}_{50}$, were prepared equivalently. All freshly prepared electrolytes were dried using molecular sieves (Fluka, $3 \AA ̊$ ) for 3 days to remove any residual water, verified by Karl-Fischer titration to result in $<20$ ppm water (Metrohm 899 coulometer). 
Half- and full cell electrochemical tests were done using CR2032 coin cells with a 304 stainless steel casing. All cells used glass fibre separators (Whatman GF/D, $675 \mu \mathrm{m}$ thick) soaked with $15 \mu \mathrm{L}$ of electrolyte and were assembled in an inert argon atmosphere inside a glovebox (MBRAUN MB200-MOD) with oxygen and water $<5 \mathrm{ppm}$. To avoid corrosion of the stainless steel, an Al-foil was cut and placed to completely cover the cathode part of the coin cell casing when using NVPF or NVP cathodes. Cells using NVP were built by adding a NVP: $\mathrm{C}_{\mathrm{sp}}$ powder electrode (see above). Assembled cells were brought to testing within 30 minutes.

\subsection{Physico-chemical characterisation}

Density $(\rho)$ and viscosity $(\eta)$ were both measured for $1 \mathrm{M}$ concentration of $\mathrm{NaPF}_{6}$ in $\mathrm{EC}_{50}: \mathrm{DMC}_{50}$ and 6 different concentrations of $\mathrm{NaPF}_{6}$ in diglyme; ranging from $0.75-2 \mathrm{M}$ and in $5^{\circ} \mathrm{C}$ steps between $10-60^{\circ} \mathrm{C}$ for $0.5 \mathrm{M}, 0.75 \mathrm{M}$, and $1.0 \mathrm{M}$ and $10-70^{\circ} \mathrm{C}$ for all other concentrations, using a DMA 4500M density meter from Anton Paar fitted with a Lovis 2000 $\mathrm{M} / \mathrm{ME}$ rolling-ball micro-viscosimeter. The viscosity was measured with the falling sphere method, using a steel ball $\left(\varnothing=1.5 \mathrm{~mm}, \rho=7.70 \mathrm{~g} \mathrm{~cm}^{-3}\right)$ and a glass capillary tube $(\varnothing=1.59$ $\mathrm{mm})$. Ionic conductivities $(\sigma)$, for the same concentrations and temperatures, were obtained by dielectric spectroscopy in the frequency range $10^{1}-10^{7} \mathrm{~Hz}$ with a broadband dielectric spectrometer (Concept 80, Novocontrol GmbH) with a Quattro Cryosystem temperature control unit. The sample cell used mirror-like brass electrodes and had an inner $\varnothing=13.7 \mathrm{~mm}$ and a thickness of $1.01 \mathrm{~mm}$, defined by a Teflon spacer. DC conductivities were obtained from the high frequency plateau of the frequency dependent $(A C)$ conductivity plots.

\subsection{Electrochemistry}

To determine the presence of any SEI growing on the Na metal anodes, electrochemical impedance spectroscopy (EIS) was conducted using Swagelok cells and symmetric $\mathrm{Na} \mid \mathrm{Na}$ electrodes, coated onto stainless steel current collectors. A Mylar ${ }^{\circledR}$ foil was used to insulate 
the plungers from the Swagelok body. Spectra were acquired using a Bio-Logic VMP-3 potentiostat, recording the impedance each $6 \mathrm{~h}$ for $96 \mathrm{~h}$ applying a $10 \mathrm{mV}$ sinusoidal voltage at frequencies ranging from $0.02 \mathrm{~Hz}$ to $200 \mathrm{kHz}$ with 10 data points sampled per frequency decade. In each $6 \mathrm{~h}$ interval the cell was left at OCV to allow the growth of any SEI to continue.

The electrochemical stability window $(E S W)$ of $1 \mathrm{M} \mathrm{NaPF}_{6}$ in diglyme was obtained by linear sweep voltammetry (LSV) at a $0.1 \mathrm{mVs}^{-1}$ scan rate using two-electrode coin cells with a Na counter/reference electrode. All potentials provided are vs. $\mathrm{Na}^{+} / \mathrm{Na}^{\circ}$. The working electrode was varied, using a range of mirror-like metal foils and mirror-like glassy carbon. NVPF and HC electrodes were used as working electrodes to test for oxidation and reduction potentials, respectively. The oxidation potential was evaluated by scanning from OCV to $5 \mathrm{~V}$ and the reduction potential by scanning from OCV to $-0.3 \mathrm{~V}$. All LSV measurements were made using a Scribner Associates 530 Battery test system.

To evaluate cycling performance, half- and full cells using $1 \mathrm{M} \mathrm{NaPF}_{6}$ in diglyme or $1 \mathrm{M}$ $\mathrm{NaPF}_{6}$ in $\mathrm{EC}_{50}: \mathrm{DMC}_{50}$ were galvanostatically cycled at room temperature using VMP-3 or MPG-2 multi-channel potentiostats (BioLogic). Cycle rates used the convention of $1 \mathrm{C}$ being equivalent to $1 \mathrm{~h}$ for a theoretical full charge ( 2 moles of Na per mole of NVPF, 1 mole of $\mathrm{Na}$ per mole of NVP, and 1 mole of Na for 6 moles of $\mathrm{HC}$ ). For full cells with HC or NVP anodes, the rates were based on the amount of cathode material, since the anode material was provided in slight excess. NVP was used both as cathode and anode depending on the cell set-up using its high and low voltage plateaus ${ }^{26,27}$. The cycling of the full cells used cell voltage windows of: 2.0-4.3 $\mathrm{V}(\mathrm{HC} \mid \mathrm{NVPF}), 0.1-2.7 \mathrm{~V}(\mathrm{NVP} \mid \mathrm{NVPF})$, and 2.0-3.5 $\mathrm{V}$ (HC|NVP). All NVP|NVP cells were initially cycled 0.0-2.3 V and subsequently 0.0-1.9 V, in order to reduce the risk of intercalation in the conductive carbon of the electrode. The half-cells were cycled 
either 0.0-2.0 V ( $\mathrm{Na} \mid \mathrm{HC})$ or 2.0-4.3 $\mathrm{V}(\mathrm{Na} \mid \mathrm{NVPF})$. Most data reported have been obtained for duplicate cells.

\subsection{Degradation analysis}

To study any electrolyte decomposition on the Na metal anode surface and any resulting gas release, a special Swagelok pressure-cell was assembled as reported elsewhere ${ }^{28}$. A 5.52 $\mathrm{mg} \mathrm{Na}$ metal disk of $4 \mathrm{~mm}$ radius and ca. $1 \mathrm{~mm}$ thickness was covered by $250 \mu \mathrm{L} 1 \mathrm{M} \mathrm{NaPF} 6$ in diglyme electrolyte at 1021 mbar ( \pm 5 mbar), whereupon the cell was sealed, moved to a workstation within 15 minutes, and the pressure evolution monitored for $>9$ days. Furthermore, to visually detect any SEI film formation as a colour change, a sphere $(5 \mathrm{~mm}$ in diameter) of Na metal was submerged in a glass vial containing $1 \mathrm{ml}$ of electrolyte, and studied for 30 days.

To further understand the degradation and the ESW of $1 \mathrm{M} \mathrm{NaPF}_{6}$ in diglyme, the LSV results were complemented by density functional theory (DFT) calculations of the oxidation and reduction potentials of diglyme, EC and DMC, and their complexes with $\mathrm{Na}^{+}$. The M06-2X functional and the $6-311++G(d, p)$ basis set were used together with the conductor-like polarizable continuum model (C-PCM) ${ }^{29}$ to account for solvent polarizability effects via the permittivity constants for THF $(\varepsilon=7.43)$ and water $(\varepsilon=78.36)$ as proxies for a weakly polar solvent - diglyme - and a high dielectric $(\varepsilon>20)$ solvent mixture $\mathrm{EC}_{50}: \mathrm{DMC}_{50}$, respectively. All computations were made using the Gaussian09 software ${ }^{30,31}$. Reduction and oxidation potentials were calculated according to an adiabatic thermodynamic cycle ${ }^{32}$, whereafter a correction of $+1.80 \mathrm{~V}$ was used to change the absolute potentials towards the $\mathrm{Na}^{+} / \mathrm{Na}^{\circ}$ scale

${ }^{33}$. The reduction/oxidation potentials are reported for the conformers showing the highest/lowest values, giving the narrowest possible ESW. 
To identify any possible non-charged electrolyte decomposition products, gas chromatography coupled to mass spectrometry (GC/MS) was performed on separators recovered from full cells after 50 cycles and half-cells after 10 cycles. The separators were soaked in $1 \mathrm{~mL}$ of dry acetonitrile $\left(\mathrm{H}_{2} \mathrm{O}<0.001 \%\right)$, removed and discarded, while the resulting solution was diluted 100 times before being injected into the GC/MS set-up, consisting of a trace 1300 series ultra-GC coupled to an ISQ MS. This protocol should allow to capture all possible residues from diglyme degradation. The chromatographic separation was performed by using a "BPX70" cyanopropylpolysilene-siloxane-based capillary column (30 m $0.25 \mathrm{~mm}$ i.d., $0.25 \mu \mathrm{m}$ film thickness) from SGE.

To identify any possible gas formed during reaction between $\mathrm{Na}$ metal and diglyme, a $\mathrm{Na}$ metal disk $(\varnothing=0.7 \mathrm{~cm}$, thickness $=1 \mathrm{~mm})$ was added to a sealed vessel containing $250 \mu \mathrm{l}$ of $1 \mathrm{M} \mathrm{NaPF}_{6}$ in diglyme and kept for 5 days. The gases were transferred into the split/splitless injector maintained at $200{ }^{\circ} \mathrm{C}$ of an ultra-GC. The chromatographic separation was performed on a "HP-PLOT/Q" polystyrene-divinylbenzene-based capillary column (30 m 0.32 $\mathrm{mm}$ i.d., $20 \mu \mathrm{m}$ film thickness) from Agilent J \&W Technologies followed by a process using a post-capillary column "Rtx-1" (15 m, $0.25 \mathrm{~mm}$ i.d., $0.25 \mu \mathrm{m}$ film thickness, $100 \%$ dimethyl polysiloxane) from Restek. 


\section{Results and Discussion}

We start by presenting the physico-chemical properties of the diglyme based electrolytes, before we evaluate Na metal as a reference electrode, paving the way for the electrochemical tests and analysis of possible electrolyte degradation products. Finally we present galvanostatic cycling analyses of half- and full cells using diglyme based electrolytes.

\subsection{Physico-chemical properties}

Any SIB electrolyte must have a high enough ion conductivity $(\sigma)$ to allow for fast and efficient ion transport even at high charge and discharge rates together with a low viscosity (n) to allow for both the rapid transport and proper wetting/soaking of the electrodes. Here we find conductivities in the range of $1-7 \mathrm{mS} \mathrm{cm}^{-1}$ and viscosities, increasing with the concentration of $\mathrm{NaPF}_{6}$, in the range of $3-7 \mathrm{mPa}$ s at $25^{\circ} \mathrm{C}$ (Table 1). This is quite comparable to carbonate based electrolytes using $\mathrm{NaPF}_{6}$ or $\mathrm{LiPF}_{6}{ }^{34}$. Furthermore, in contrast to previous reports for glyme-based LIB electrolytes using $\operatorname{LiPF}_{6}{ }^{23,24}$, we found the solubility limit of $\mathrm{NaPF}_{6}$ to be $\geq 2 \mathrm{M}$ (no maximum solubility test was made). Despite the comparatively low dielectric constant of diglyme $(7.4)^{35}$ as compared to $\mathrm{EC}(89.8)^{36}$ in $\mathrm{EC}_{50}$ :DMC 50 , the ionic conductivities are of the same order of magnitude for both electrolytes. The reason can be inferred to be the chelating coordination mode of glymes to small cations, successful in dissociating salts even though the solvent itself is relatively unpolar ${ }^{22}$. At the same time the degree of salt dissociation seems crucial - as these $\mathrm{NaPF}_{6}$ based electrolyte all have higher conductivities than the corresponding NaTf based and the latter, as shown by diffusion NMR, have extensive ion-ion interactions resulting in the transport numbers for the $\mathrm{Na}^{+}$cation and the $\mathrm{Tf}$ anion to both be $0.5^{21}$. The degree of ion-pair association can be further analysed using a Walden-plot (Figure 1a). Aqueous $\mathrm{KCl}$ (dashed line) is often used as a reference for a 
completely dissociated salt, i.e. no ion-pairs, and thus a lower salt dissociation degree shifts the data below and away from the reference line ${ }^{37,38}$. Here the least concentrated diglyme based electrolyte apparently exhibits the lowest ion-pair dissociation, but as proposed by MacFarlane et al., a larger effective ionic radius should be accounted for when comparing any electrolyte to $\mathrm{KCl}(\mathrm{aq})^{37}$, especially important here as the proposed solvation of $\mathrm{Na}^{+}$by diglyme is qualitatively different, chelating, as compared to solvents with mono-dentate coordination.

Table 1. Physico-chemical properties of diglyme (G2) and $\mathrm{EC}_{50}: \mathrm{DMC}_{50}$ based electrolytes@25ㄷ

\begin{tabular}{lllll}
$\begin{array}{llll}\text { Concentration } \\
{\left[\mathrm{mol} \mathrm{dm}^{-3}\right]}\end{array}$ & $\begin{array}{l}\text { Density, } \rho \\
{\left[\mathrm{g} \mathrm{cm}^{-3}\right]}\end{array}$ & $\begin{array}{l}\text { Viscosity, } \eta \\
{[\mathrm{mPa} \mathrm{s}]}\end{array}$ & $\begin{array}{l}\text { Ion conductivity, } \sigma \\
{\left[\mathrm{mS} \mathrm{cm}^{-1}\right]}\end{array}$ & $\begin{array}{l}\text { Molar conductivity, } \Lambda \\
{\left[\mathrm{S} \mathrm{cm}^{2} \mathrm{~mol}^{-1}\right]}\end{array}$ \\
\hline 1.75 & 1.03 & 2.13 & 3.54 & 4.6 \\
1.0 & 1.04 & 2.42 & 5.64 & 5.6 \\
1.50 & 1.08 & 3.71 & 5.97 & 5.0 \\
1.75 & 1.11 & 4.81 & 6.76 & 4.8 \\
2.0 & 1.13 & 6.46 & 6.79 & 4.2 \\
1.0 & 1.16 & 9.15 & 6.51 & 3.1 \\
$\left(\mathrm{EC}_{50}\right.$ :DMC & & & 11.5 & 12
\end{tabular}

Furthermore, the Walden plot can be used to evaluate the consistency of the fractional Walden rule, relating the molar conductivity $(\Lambda)$ to the viscosity $(\eta)$ according to:

$$
\begin{gathered}
\Lambda \cdot \eta^{\alpha}=c \\
\log _{10}(\Lambda)=\log _{10}(c)+\alpha \cdot \log _{10} \frac{1}{\eta}
\end{gathered}
$$


, where the Walden coefficient $0<\alpha \leq 1$ and $c=10^{c}$ is a constant ${ }^{39}$. The closer $\alpha$ gets to 1 , the closer the Arrhenius activation energy for the conductivity comes to that of the viscosity ${ }^{38,39}$. The fractional Walden rule appears to hold for all the diglyme based electrolytes, with one dimensional polynomials fitting the data closely. The Walden coefficients increase with increasing salt concentration (Figure 1b), indicating a transition from sub-ionic to vehicular/viscosity limited conduction. We observe no discontinuities indicating phase transitions in neither viscosity, density, nor ionic conductivity, allowing us to choose $1 \mathrm{M}$ $\mathrm{NaPF}_{6}$ in diglyme for our further investigations.
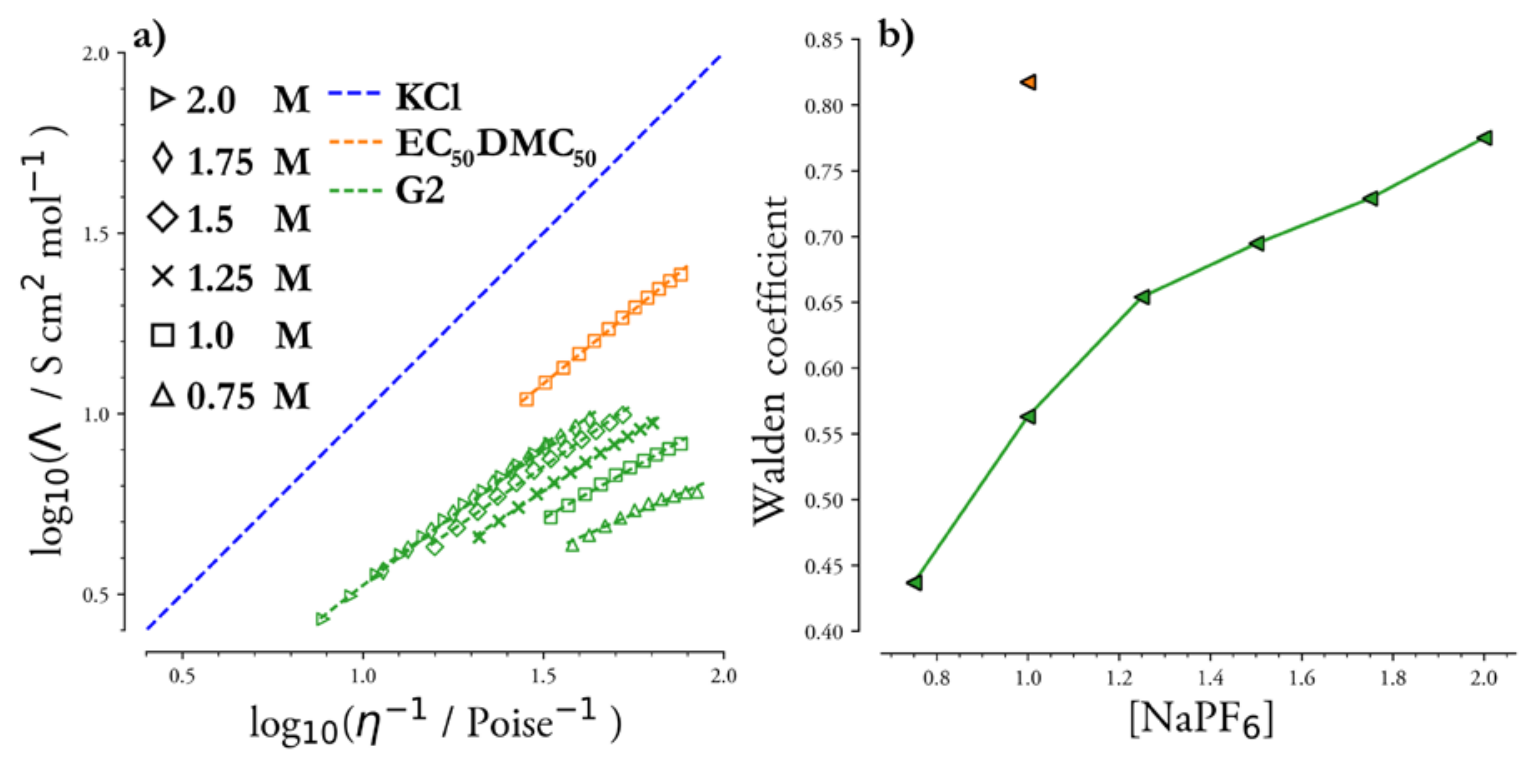

Figure 1. Walden plot (a) and Walden coefficients (b) for the different electrolytes.

The estimated systematic error is within the size of the symbols used.

\subsection{Na metal as a reference electrode}

Being able to use Na metal as a reliable reference electrode allows for cheap and rapid electrolyte and electrode screening. Here EIS was employed to study the reliability of the $\mathrm{Na}$ metal reference electrodes along with the reductive stability and SEI formation of $1 \mathrm{M} \mathrm{NaPF}_{6}$ in diglyme in symmetric $\mathrm{Na}$ | Na cells. The impedance profile shrinks and stabilises with time 
at OCV (Figure 2) and after $36 \mathrm{~h}$ the spectra do not further evolve. While this implies that no SEI formation can be detected, it is no proof of the electrolyte being reductively stable against Na metal.

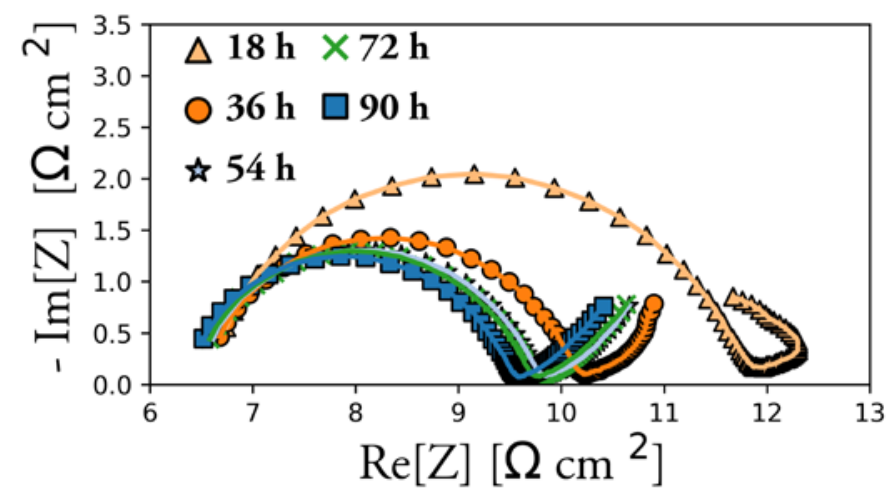

Figure 2. Impedance spectra for a symmetric $\mathrm{Na}$ | $\mathrm{Na}$ cell at OCV.

To further test for reduction reactions, the gas evolution from storing Na metal in $1 \mathrm{M}$ $\mathrm{NaPF}_{6}$ in diglyme was studied (Figure 3 ) and the pressure as a function of time shows that an equilibrium of $c a .1 .05$ bar is reached after $150 \mathrm{~h}$. This corresponds to $5 \times 10^{-3}$ moles of gas per mole of available $\mathrm{Na}$ or ca. $21 \mu \mathrm{mol} \mathrm{cm}{ }^{-2}$ (surface area of available $\mathrm{Na}$ ) developed, as calculated by the ideal gas law. Note that the actual starting pressure is not seen at $0 \mathrm{~h}$, but rather the glove-box pressure at time of assembly (1021 \pm 5 mbar). 


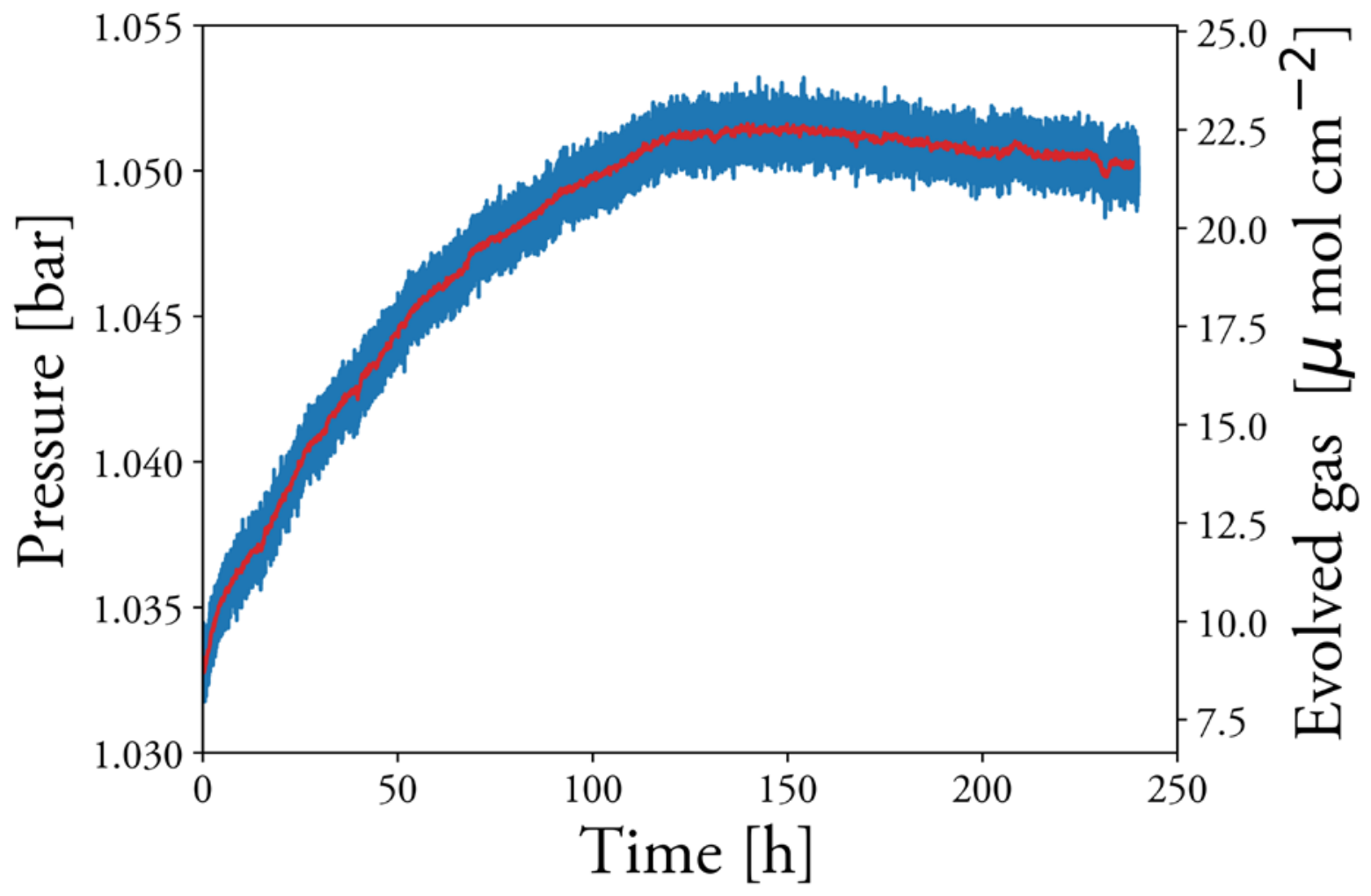

Figure 3. Pressure evolution at $25^{\circ} \mathrm{C}$ from $\mathrm{Na}$ metal stored in $1 \mathrm{M} \mathrm{NaPF}_{6}$ in diglyme.

To set this in perspective, Dugas et al. showed that $1 \mathrm{M} \mathrm{NaPF}_{6}$ in $\mathrm{EC}_{50}: \mathrm{DMC}_{50}$ experiences a continuous gas evolution reaching $>0.3$ moles of gas per mole of available $\mathrm{Na}$, hence 2 orders of magnitude larger ${ }^{40}$. Using diglyme thus clearly prevents any pronounced continuous gas evolution and this can be due either to the decomposition product(s) forming a passivating SEI and/or to the formation of precipitating/soluble species. Such species must be colourless, indicated by the absence of colour change from a Na sphere stored in the $1 \mathrm{M} \mathrm{NaPF}_{6}$ in diglyme electrolyte for 30 days (Figure 4). A third option is that the electrolyte is completely stable; since a PTFE ring is used and contacted with $\mathrm{Na}$ in the cell, the small gas evolution observed could arise from the etching of this ring, as has been observed in industrial applications ${ }^{41}$. Indeed, the ring did display a blackened surface upon inspection after disassembling the set-up. 


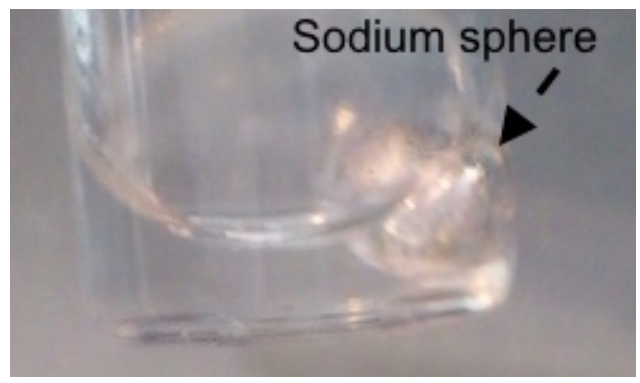

Figure 4. A Na metal sphere stored in $1 \mathrm{M} \mathrm{NaPF}_{6}$ in diglyme.

\subsection{ESWs of diglyme based electrolytes}

For use in SIBs, a wide ESW is desired to allow for a large range of electrode materials to be practically usable. Exploiting Na metal as a stable reference electrode all substrates showed pronounced electrolyte oxidation only above $4.4 \mathrm{~V}$ (Figure 5). While this is $>1 \mathrm{~V}$ lower than for $1 \mathrm{M} \mathrm{NaPF}_{6}$ in $\mathrm{EC}_{50}: \mathrm{DMC}_{50}$, which shows no pronounced oxidation $<5 \mathrm{~V}$ (Figure $\mathrm{S} 4$ ), it is still $0.3 \mathrm{~V}$ above the second extraction peak of the NVPF cathode material at ca. $4.1 \mathrm{~V}$ (purple, Figure 5). The (catalytic properties of) different substrates shift the oxidation by ca. $0.2 \mathrm{~V}$ with NVPF and Cu rendering the lowest onsets, ca. $4.4 \mathrm{~V}$, and glassy carbon and Au providing the highest onsets, ca. 4.6 V. Al results in no clear onset, in agreement with Eshetu et al. suggesting passivation by anion oxidation and formation of fluoroaluminates ${ }^{14}$, possibly detectable at ca. 3.4 V (orange, inset Figure 5). A similar peak also occurs at this voltage for NVPF (purple, Figure 5), most likely due to a contamination by NVP, as it exactly matches the extraction potential of $\mathrm{Na}^{+}$from NVP ${ }^{27,42}$. Finally, also $\mathrm{Cu}$ shows a minor peak at $3.5 \mathrm{~V}$ (green, inset Figure 5), likely related to anion decomposition and more pronounced for the $\mathrm{EC}_{50}: \mathrm{DMC}_{50}$ based electrolytes (Figure S4). 


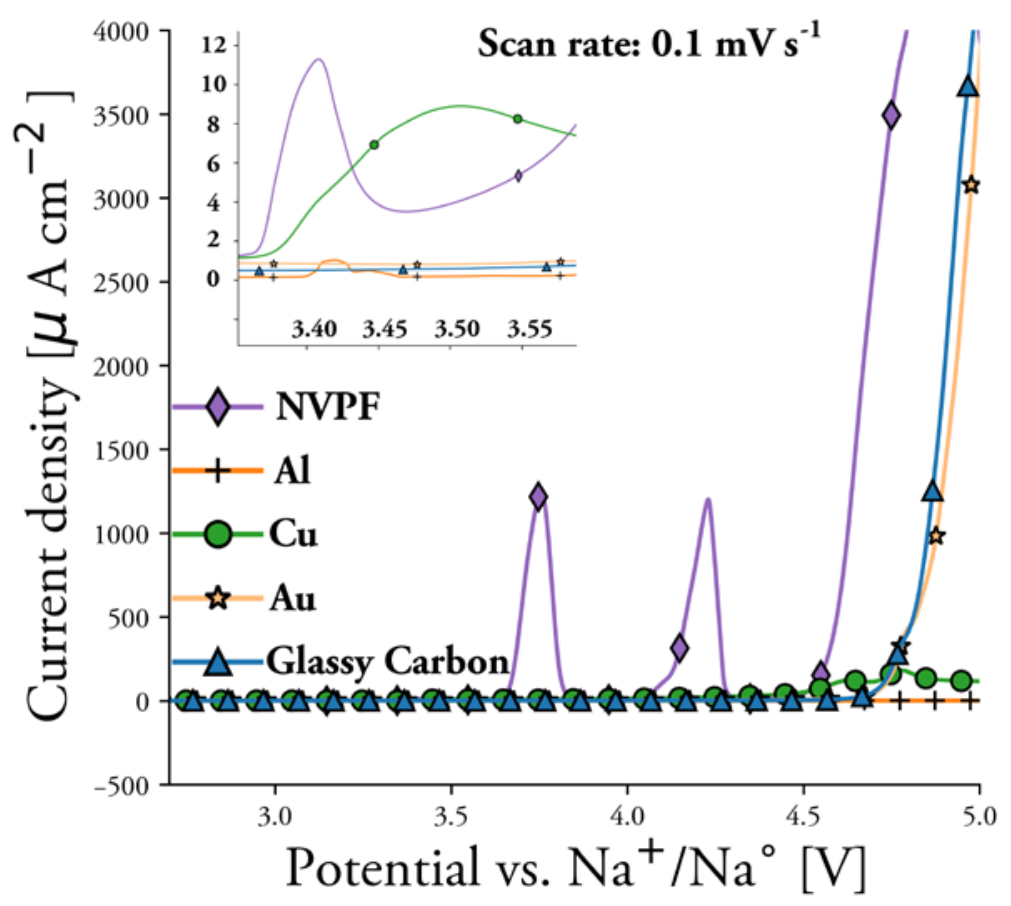

Figure 5. Linear sweep voltammograms of the oxidative behaviour of $1 \mathrm{M} \mathrm{NaPF}_{6}$ in diglyme. Inset: 3.35-3.60 V.

Large reductive current densities $\left(>7 \mathrm{~A} \mathrm{~cm}^{-2}\right)$ occur below $0 \mathrm{~V}$ for the non-electrochemically active substrates (Figure 6), likely due to Na plating ${ }^{17}$. The small reductive currents $(1 \mu \mathrm{A} \mathrm{cm}-$ ${ }^{2}$ ) observed already above 1.2 V for all substrates except Al are solvent independent and have previously been assigned to parasitic reactions involving $\mathrm{H}_{2} \mathrm{O}$ or $\mathrm{O}_{2}$ contaminations or possibly slow electrolyte reduction ${ }^{43}$. For the electrochemically active $\mathrm{HC}$ the main current arises from intercalation of $\mathrm{Na}^{+}$, but in addition there is a minor feature at ca. $1 \mathrm{~V}$ possibly related to electrolyte reduction. Also glassy carbon exhibits some electrochemical activity, as expected ${ }^{44-46}$. 


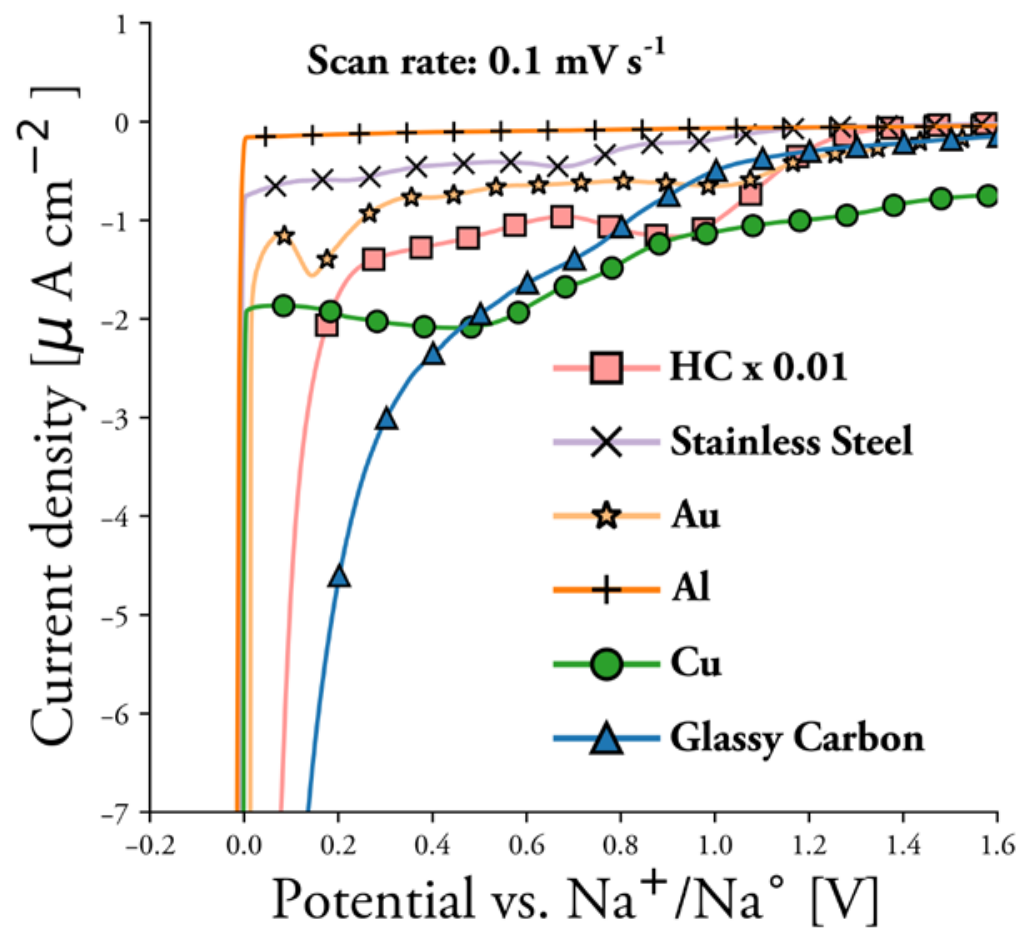

Figure 6. Linear sweep voltammograms of $1 \mathrm{M} \mathrm{NaPF}_{6}$ in diglyme electrolyte for different working electrodes. Note the 0.01 multiplying factor for the HC curve.

To support the interpretation of LSV data on reduction/oxidation of diglyme DFT calculations were performed for pure solvents and various complexes (Table 2). For diglyme all calculated reduction and oxidation potentials are below $0 \mathrm{~V}$ and above $4.7 \mathrm{~V}$. EC complexed by $\mathrm{Na}^{+}$has a reduction potential of $1.21 \mathrm{~V}$, pure $\mathrm{EC}$ has a $\mathrm{U}_{\text {red }}$ of $1.16 \mathrm{~V}$, while diglyme exhibits a reduction potential between $-1.29-(-0.54) \mathrm{V}$. DMC complexed by $\mathrm{Na}^{+}$is the least stable: $1.85 \mathrm{~V}$. Hence we do not as a first approximation expect any decomposition of diglyme until $<0 \mathrm{~V}$. A more detailed analysis of the possible reduction schemes and its products result in slightly higher reduction potentials and an idea about the bonds more prone to break (Table 3 ). In addition, the possible effect (bond scissoring) of any $\mathrm{PF}_{5}$ available has not been accounted for ${ }^{47}$. 
Table 2. Calculated reduction $\left(U_{\text {red }}\right)$ and oxidation potentials $\left(U_{\mathrm{ox}}\right)$ for diglyme and carbonate solvents and $\mathrm{Na}^{+}$complexes.

\begin{tabular}{lll} 
Species & $\mathrm{U}_{\text {red }}$ Vs. $\mathrm{Na}^{+} / \mathrm{Na}^{\circ}$ & $\mathrm{U}_{\text {ox }}$ Vs. $\mathrm{Na}^{+} / \mathrm{Na}^{\circ}$ \\
\hline $\mathrm{G} 2$ & -1.29 & 5.83 \\
{$[\mathrm{Na}(\mathrm{G} 2)]^{+}$} & -0.54 & 6.86 \\
{$\left[\mathrm{Na}(\mathrm{G} 2)_{2}\right]^{+}$} & -1.05 & 6.52 \\
{$\left[\mathrm{Na}(\mathrm{G} 2)_{2}\right]^{+}\left[\mathrm{PF}_{6}\right]^{-}$} & -1.07 & 5.89 \\
{$\left[\mathrm{G} 2(\mathrm{PF})_{6}\right]^{-}$} & $\mathrm{n} / \mathrm{a}$ & 4.72 \\
$\mathrm{EC}$ & $1.16^{48}$ & 6.86 \\
$\mathrm{DMC}$ & $0.56^{48}$ & 6.36 \\
{$[\mathrm{Na}(\mathrm{EC})]^{+}$} & 1.21 & 7.01 \\
{$[\mathrm{Na}(\mathrm{DMC})]^{+}$} & 1.85 & 6.54
\end{tabular}

Table 3. Calculated reduction potentials $\left(U_{\text {red }}\right)$ for scissoring of bonds in diglyme at different levels of complexation with $\mathrm{Na}^{+}$.

\begin{tabular}{llll} 
Species & Bond & $\mathrm{U}_{\text {red }} V s . \mathrm{Na}^{+} / \mathrm{Na}^{\circ}[\mathrm{V}]$ & $\mathrm{E}_{\mathrm{a}}[\mathrm{eV}]$ \\
\hline $\mathrm{G} 2$ & $\mathrm{C}_{1}-\mathrm{O}_{1}$ & -1.14 & 0.767 \\
& $\mathrm{O}_{1}-\mathrm{C}_{2}$ & -1.21 & 0.774 \\
& $\mathrm{C}_{2}-\mathrm{O}_{2}$ & -1.12 & 0.728 \\
\hline$[\mathrm{Na}(\mathrm{G} 2)]^{+}$ & $\mathrm{C}_{1}-\mathrm{O}_{1}$ & -0.07 & 1.02 \\
& $\mathrm{O}_{1}-\mathrm{C}_{2}$ & -0.21 & 0.847 \\
& $\mathrm{C}_{2}-\mathrm{O}_{2}$ & -0.11 & 0.841 \\
\hline & $\mathrm{C}_{1}-\mathrm{O}_{1}$ & -0.21 & 0.392 \\
{$\left[\mathrm{Na}(\mathrm{G} 2)_{2}\right]^{+}$} & $\mathrm{O}_{1}-\mathrm{C}_{2}$ & -0.32 & 0.667 \\
& $\mathrm{C}_{2}-\mathrm{O}_{2}$ & -0.29 & 0.672
\end{tabular}




\subsection{Degradation Mechanism and Schemes}

Even though we by DFT calculations and LSV measurements did not find anything pointing towards any major reduction of diglyme, further measures to characterise possible electrolyte degradation to elucidate the reaction pathways were taken. Explanation models for irreversibilities when cycling other electrolytes in full cells have attributed losses to SEIformation, growing through reduction of the electrolyte ${ }^{36,47}$. The reduction could possibly also be coupled to formation of soluble decomposition products ${ }^{49,50}$. Separators from cycled full and half-cells were analysed using GC/MS, previously shown successful in identifying reduction products from carbonate based electrolytes ${ }^{51,52}$

The resulting chromatograms indicated no soluble light, non-charged, reduction products the only peaks appearing being those from acetonitrile and diglyme (Figure 7). This is, however, not any definitive evidence for a lack of electrolyte reduction. The reduction products can be salts; not dissolved or gasified, or radicals; polymerising to form large oligomers beyond the GC/MS set-up detection range. 


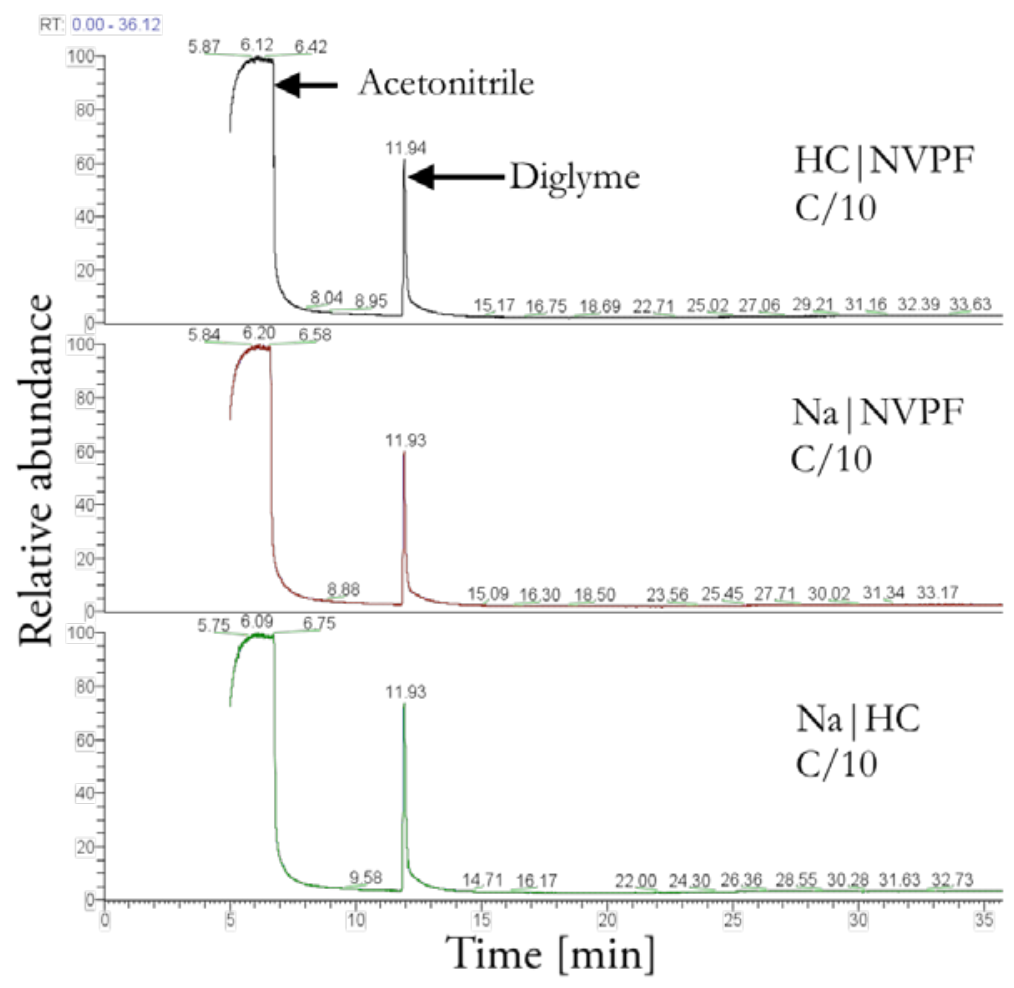

Figure 7. GC data for cycled separators.

To complement the solution based analysis, the gas evolved from Na metal stored in diglyme for 5 days was analysed, but showed no major features (Figure 8). This point towards the major part of the gas release seen in Section 3.2 to be the result of sodium incompatibility with the PTFE in the pressure cell rather than from reduction of the solvent. 


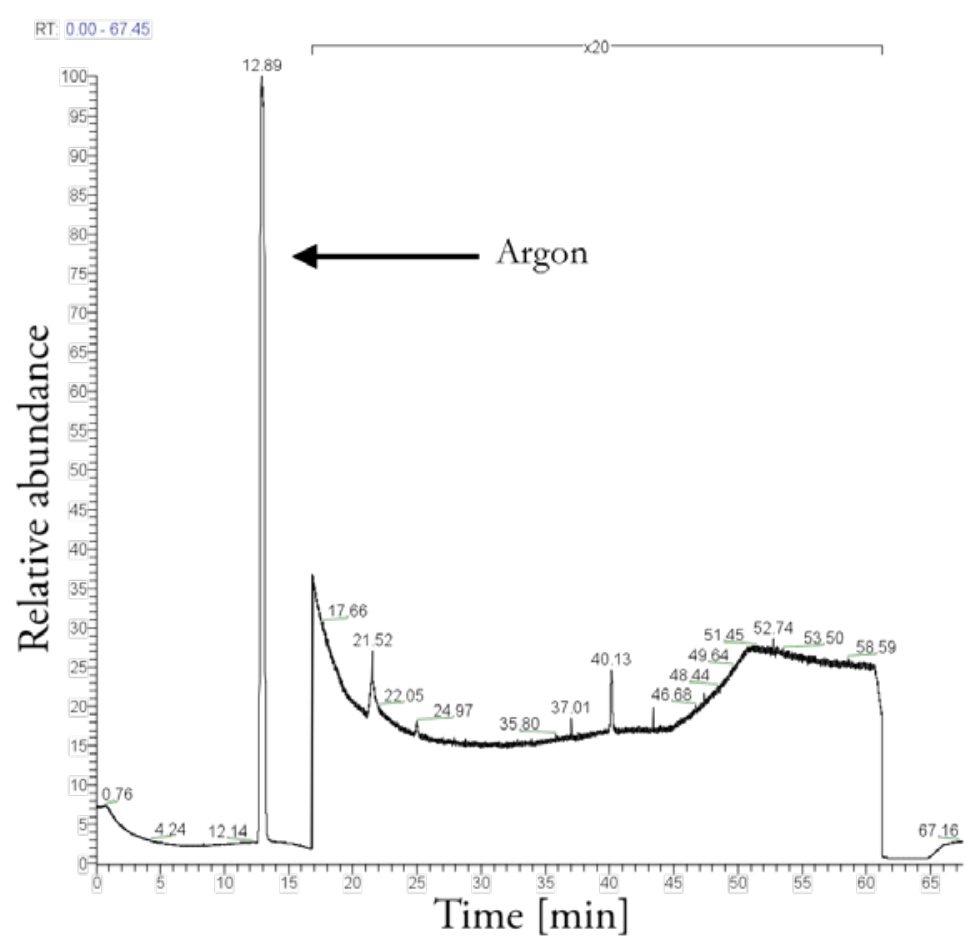

Figure 8. GC data from reduction products of Na metal stored in diglyme.

Note that a multiplication factor 20 has been applied to part of the data.

When mapping out possible reaction pathways (Figure S5, S6 and S7), a number of kinetically possible reduction pathways were seen. However, with the lack of soluble, noncharged degradation products and gases, the most probable reduction mechanisms for diglyme are those only including polymerisation and alkoxide formation, similar to the LIB processes suggested by Zhuang and Ross ${ }^{49}$. A complementing FTIR analysis of cycled cell anodes (Figure S8) did not indicate any such species, but should be interpreted with care due to the experimental difficulties of keeping the integrity of an SEI upon cell disassembly.

\subsection{SIB cell tests}

The indications of an ESW of $1 \mathrm{M} \mathrm{NaPF}_{6}$ in diglyme matching the redox potentials of $\mathrm{HC}$ and NVPF and that no reduction products were detected using GC/MS, motivated testing the electrolyte in half-cells of Na|NVPF and $\mathrm{Na} \mid \mathrm{HC}$, and in HC|NVPF full cells. For the Na|HC 
half-cells the characteristic slope and plateau of $\mathrm{HC}$ are both clearly reproduced (Figure 9a) ${ }^{9}$. Likewise, the Na|NVPF half-cells reproduce profiles in the literature with two plateaus at 3.6 and $4.1 \mathrm{~V}$ (Figure $9 \mathrm{~b})^{11}$. Both materials suffer from an initial irreversibility; for NVPF the $3 \%$ is probably related to the NVP contamination undergoing an irreversible phase transition at the high potentials experienced, while for $\mathrm{HC}$ the $23 \%$ should be attributed to some initial parasitic process consuming $\mathrm{Na}$. The initial sloping region in the $\mathrm{HC}$ charge profile relates to the bulge in the derivative curve between 0.4 and $1.4 \mathrm{~V}$, before a sharp peak due to the insertion of $\mathrm{Na}$ (Figure 9c). During the first charge there is a small peak appearing at ca. 1.02 $V^{7}$. A conventional attribution is to ascribe this to the formation of an SEl by reduction of the electrolyte ${ }^{47}$, but this has little or no support from the present LSV analysis on metallic substrates and is rather attributable to an intrinsic process of HC. The irreversibility during the first cycle is larger for the diglyme (ca. 23\%) than the alkylcarbonate (ca. 17\%) based electrolytes. This is surprising given the formation of relatively thick SEls using alkyl carbonate based electrolytes ${ }^{36}$ while we failed to find any evidence for a passivation layer using diglyme as electrolyte solvent. We can only speculate this to be related to sodium trapping in $\mathrm{HC}$ or $\mathrm{C}_{\mathrm{sp}}$, as previously observed in $\mathrm{HC}^{53}$ and annealed coke ${ }^{54}$. In addition, parasitic reactions involving the PVDF binder cannot be excluded. 

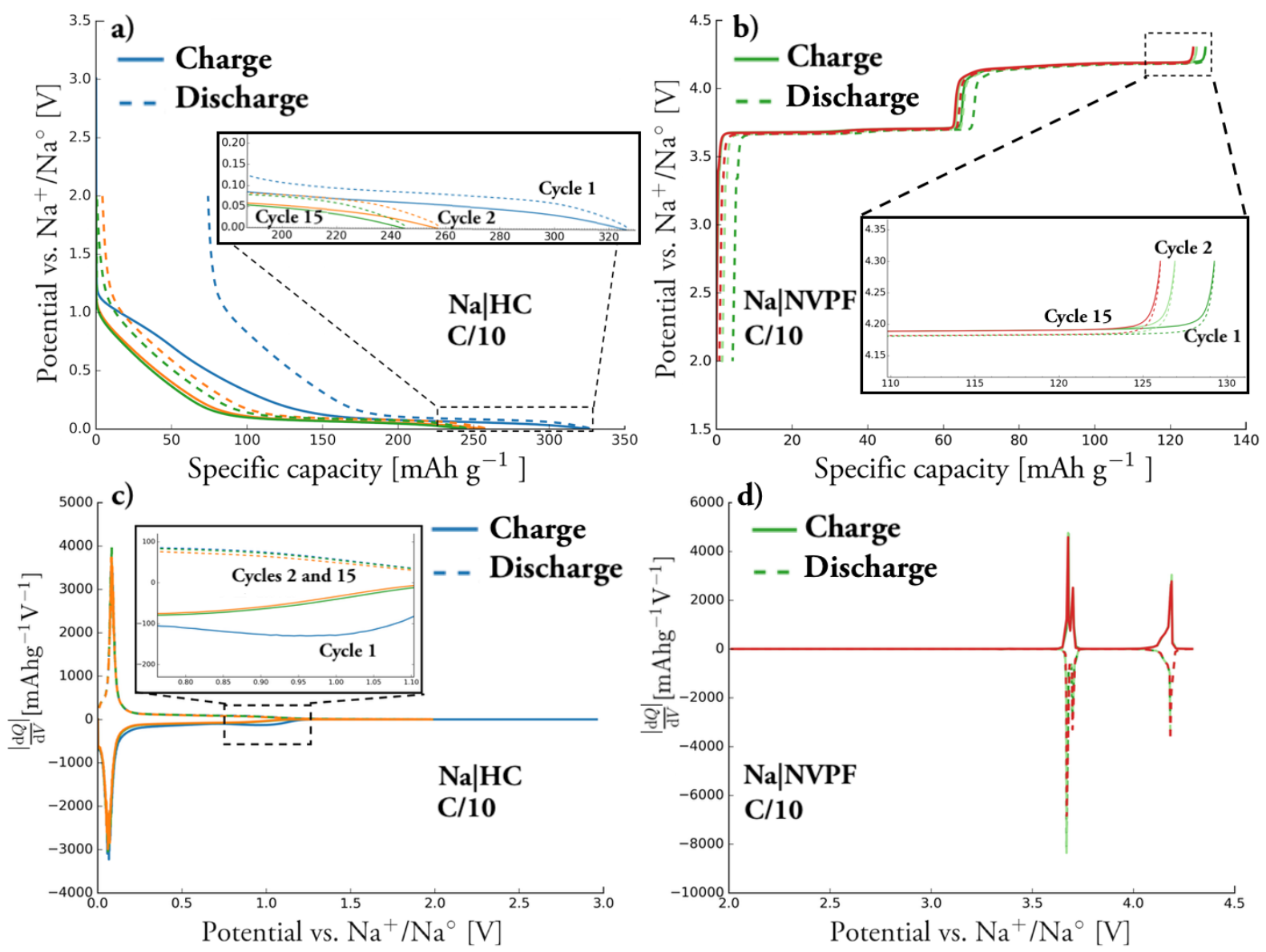

Figure 9. Typical cell cycling profiles of a) $\mathrm{Na} \mid \mathrm{HC}$ and b) Na|NVPF half-cells with the

$1 \mathrm{M} \mathrm{NaPF}_{6}$ in diglyme electrolyte, and c) and d) the corresponding differential capacity

profiles.

For NVPF there are only small differences among the subsequent cycles, and the differential capacity profiles show three clear peaks; the first two relate to the two first subplateaus and the third to the second main plateau (Figure $9 \mathrm{~b}$ and $9 \mathrm{~d})^{11}$.

The coulombic efficiencies of the Na|NVPF and Na|HC half-cells and the NVPF|HC full cell show both half-cells to arrive at an efficiency of ca. $99.5 \%$ after five cycles, whereas the full cell remains at ca. $99 \%$ (Figure 10). This translates in a poor capacity retention of the full cell (Figure 10, orange). Since the discharge of the full cell is limited by HC desodiation, the capacity loss in the full cell is at a first level of approximation expected to reflect the 
irreversibility of the $\mathrm{HC}$ anode. Indeed, if the actual anode coulombic efficiency is accumulated cycle by cycle (to account for the absence of Na reservoir in the full cell), $7.4 \%$ of the capacity is lost in 15 cycles (Figure 10, green). Assuming a $0.5 \%$ uncertainty in the HC efficiency (dashed lines), the actual capacity retention of the full cell is within the error.

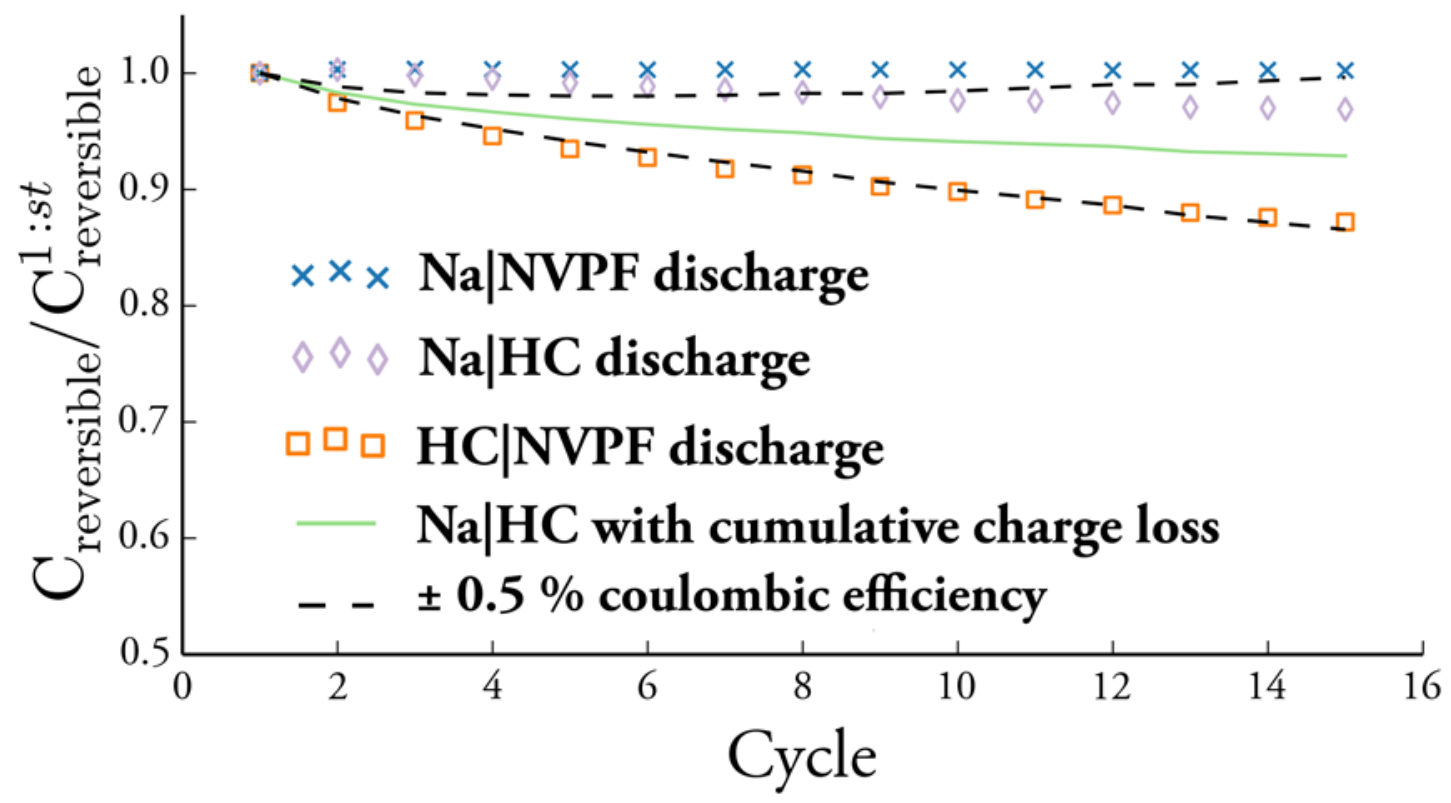

Figure 10 . Reversible capacities $\left(C_{\text {reversible }}\right)$ normalised by the discharge capacity on first cycle $\left(\mathrm{C}^{1 \text { st }}\right.$ reversible $)$ for full and half-cells of NVPF and $\mathrm{HC}$ using the $1 \mathrm{M} \mathrm{NaPF}_{6}$ in diglyme electrolyte.

This indicates that the efficiency of the anode sodiation and desodiation process can account for the fast decay of the full cell capacity. The capacity retention of the full cell being at the lower limit of the uncertainty domain suggests that a secondary process may affect the cyclability, such as dissolution of the NVP impurity, or that HC composite electrode irreversibility could come to a higher extent from the initial (sloping) stage, assigned to insertion between graphene layers ${ }^{46}$, since the full cells were constructed with a slight 
surplus of $\mathrm{HC}$ and that the complete cycling profiles seen for the $\mathrm{Na|HC}$ cells were not traversed in the full cells.

In contrast, no or little loss in capacity is believed to arise from the NVPF electrode, as indicated by the asymmetric loss between the characteristic lower/upper NVPF plateaus in the full cells (Figure 11). The upper plateau stability indicates the capacity of NVPF to remain constant during cycling. The capacity retention test of the HC|NVPF full cell shows ca. $30 \%$ of the capacity to be lost during the first cycle and subsequently a continuous capacity fade of ca. $0.45 \mathrm{mAh} \mathrm{g}^{-1}$ per cycle $(0.35 \%$ of the initial capacity per cycle) (Figure 12). For the same set-up using $1 \mathrm{M} \mathrm{NaPF}_{6}$ in $\mathrm{EC}_{50}: \mathrm{DMC}_{50}$ as the electrolyte $c a .19 \%$ and $c a .0 .15 \mathrm{mAh} \mathrm{g}^{-1}$ per cycle $(0.12 \%$ of the initial capacity per cycle) are observed (Figure 12$)$. Thus the $1 \mathrm{M} \mathrm{NaPF}_{6}$ in diglyme electrolyte both has a larger initial irreversible capacity loss and a worse long term capacity retention. We suggest two hypotheses: either HC composite electrode has lower reversibility in the diglyme based electrolyte than in the $\mathrm{EC}_{50}: \mathrm{DMC}_{50}$ based, or electrolyte oxidation at the cathode counter-balances the anode irreversibility when using the $\mathrm{EC}_{50}: \mathrm{DMC}_{50}$ based electrolyte, leading to a lower capacity fade. 


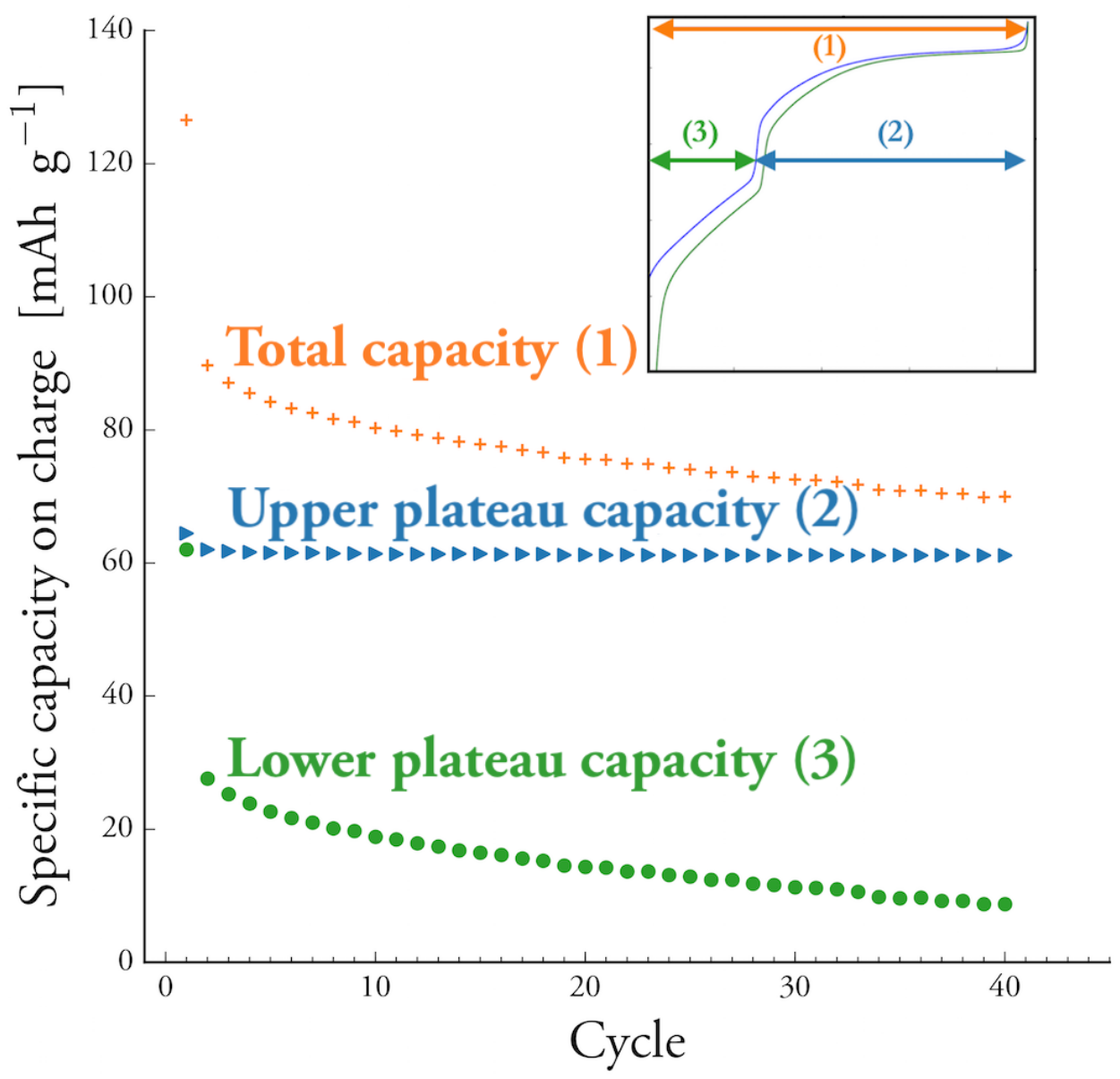

Figure 11. Evolution of the two plateaus upon cycling of the $\mathrm{HC} \mid 1 \mathrm{M} \mathrm{NaPF}_{6}$ in diglyme|NVPF full cell between 2.0-4.3 V. Inset: the partitioning of the full cell capacity profile. 


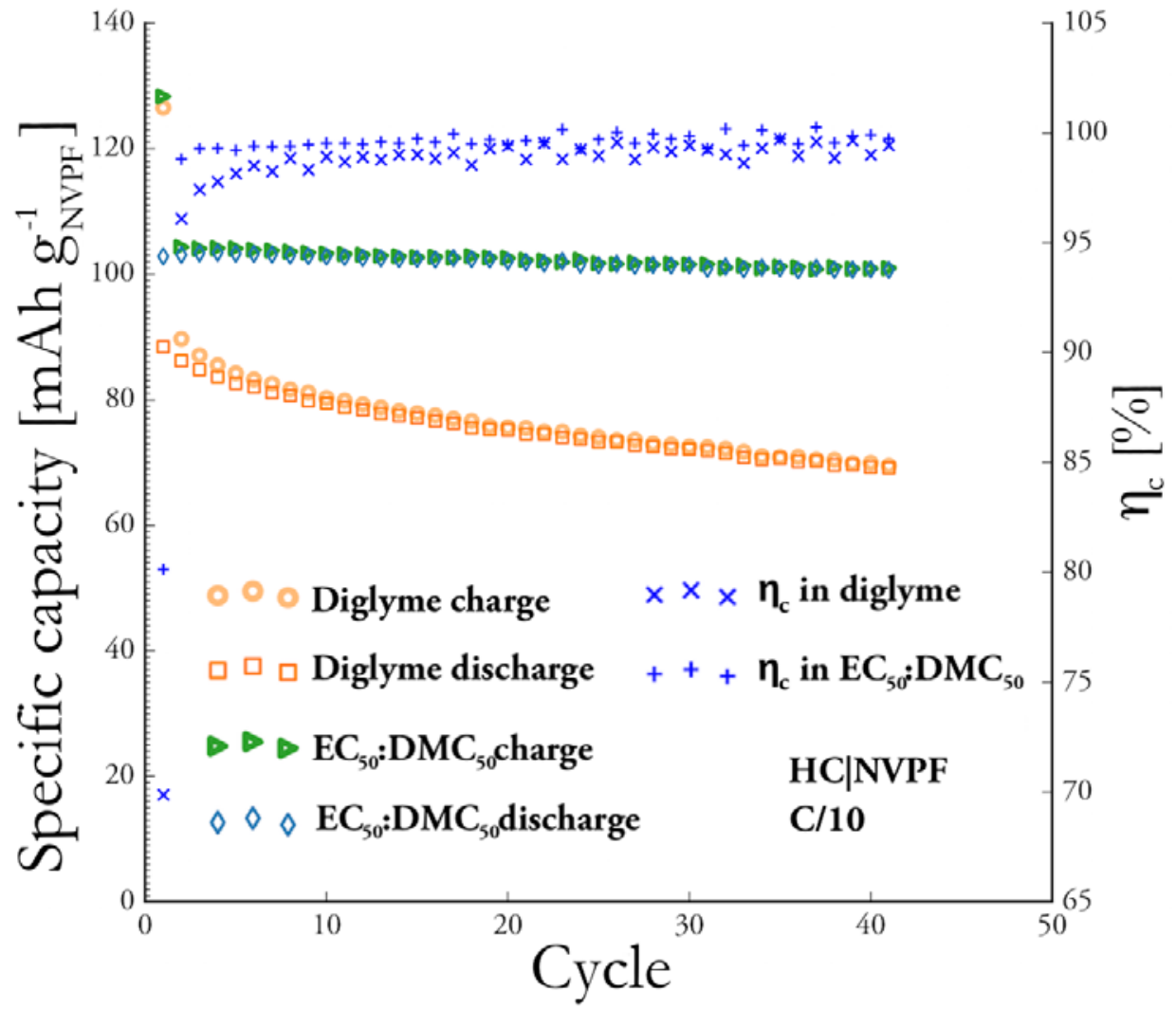

Figure 12. Capacity retention and coulombic efficiency $\left(n_{c}\right)$ for $\mathrm{C} / 10$ cycling of $\mathrm{HC} \mid N V P F$ full cells using $1 \mathrm{M} \mathrm{NaPF}_{6}$ in diglyme or $1 \mathrm{M} \mathrm{NaPF}_{6}$ in $\mathrm{EC}_{50}: \mathrm{DMC}_{50}$ as electrolyte.

NVP|NVP cells were used to explore a different potential range; when used both as cathode $\left(3.4 \mathrm{~V}\right.$ vs. $\left.\mathrm{Na}^{+} / \mathrm{Na}^{\circ}\right)$ and as anode $\left(1.6 \mathrm{~V} \text { vs. } \mathrm{Na}^{+} / \mathrm{Na}^{\circ}\right)^{27}$, this indeed results in very small capacity losses with a high coulombic efficiency (Figure 13), showing that stable cell cycling is possible using a diglyme based electrolyte. 


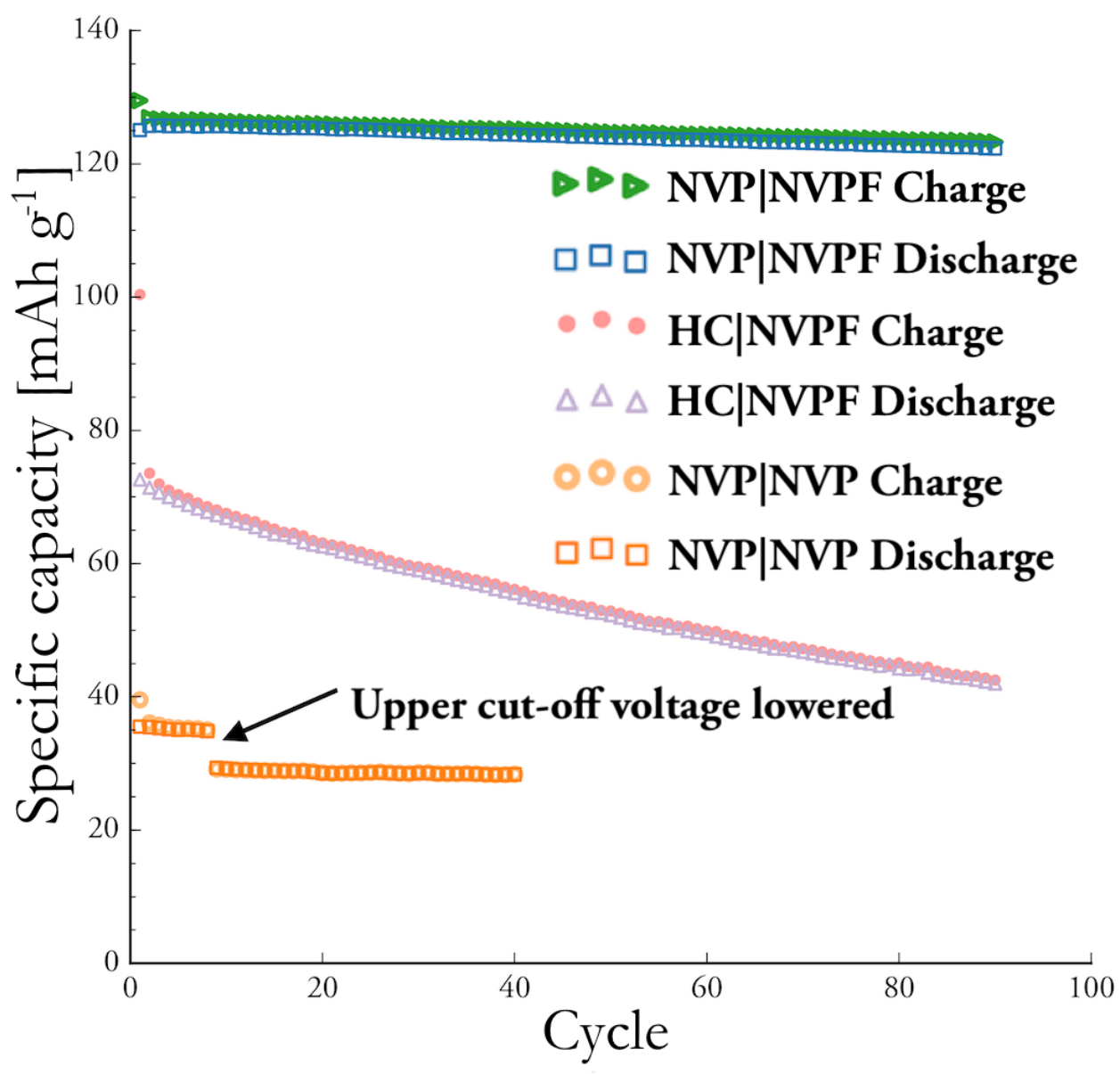

Figure 13. Specific capacity retention; for the NVP|NVP cells the anodic capacity is used, while for both the HC|NVP and NVP|NVPF cells the cathodic capacity is used. For the NVP|NVP cells the lower cut-off potential was changed from $2.8 \mathrm{~V}$ to $2.0 \mathrm{~V}$ during the experiment, which improved the capacity retention.

Using NVP in HC|NVP and NVP|NVPF full cells the capacity fade was most pronounced for the HC|NVP cells (Figure 13), amounting to $0.34 \mathrm{mAh} \mathrm{g}^{-1} \mathrm{cycle}^{-1}(0.33 \%$ of the initial discharge capacity per cycle) with an initial irreversibility of $27.7 \%$. Corresponding values for the NVP |NVPF cells are $0.028 \mathrm{mAh} \mathrm{g}^{-1}$ cycle $^{-1}(0.025 \%$ of the initial discharge capacity per cycle) with an initial irreversibility of $3.4 \%$. The HC|NVP data matches that of the HC|NVPF cell surprisingly well and further supports our interpretation of an anodic parasitic process 
occurring at the $\mathrm{HC}$ composite electrode being main responsible for both the initial and the continuous capacity fade.

\section{Conclusions}

Our thorough evaluation of diglyme as a room-temperature SIB electrolyte solvent suggest the ionic conductivity of $\mathrm{NaPF}_{6}$ in diglyme to be comparable to employing a $\mathrm{EC}_{50}: \mathrm{DMC}_{50}$ solvent mixture and the Walden plot indicate a sub-ionic behaviour for the lowest salt concentrations. Na metal is found to be appropriate as a reference electrode and the ESW of $1 \mathrm{M} \mathrm{NaPF}_{6}$ in diglyme indicates no major reductive or oxidative decomposition within 0-4.4 $\mathrm{V}$ vs. $\mathrm{Na}^{+} / \mathrm{Na}^{\circ}$. The latter indicates either formation of a relatively stable SEI or more likely a lack of reduction, supported by DFT calculations of oxidation and reduction potentials for various complexes of diglyme with $\mathrm{Na}^{+}$and $\mathrm{PF}_{6}^{-}$, and $\mathrm{GC} / \mathrm{MS}$ analyses.

Half-cells of $\mathrm{Na} \mid \mathrm{NVPF}$ and $\mathrm{Na} \mid \mathrm{HC}$ using $1 \mathrm{M} \mathrm{NaPF}_{6}$ in diglyme largely replicate the voltage profiles in the literature for carbonate based electrolytes ${ }^{9,11,15,25}$. HC|NVPF full cells exhibit a high initial irreversibility and a pronounced continuous capacity fade. In contrast, the NVP based cells show a very stable cycling and no initial irreversibility.

The large irreversible capacities observed when using $\mathrm{HC}$ composite electrodes urges for more thorough investigations targeting possible non-conventional, SEI-related, side-reactions such as sodium trapping within $\mathrm{HC}$ or carbon additives and/or involving the binder.

\section{Acknowledgements}

We acknowledge the European Commission for the financial support for "Na-ion Battery Demonstration for Electric Storage" (NAIADES) under research grant agreement No. 646433 and especially L. Simonin and Y. Chatillon (CEA, Grenoble, France) for the NVPF material and 
for sharing high purity $\mathrm{NaPF}_{6}$. We also acknowledge funding from the Swedish Energy Agency from "Batterifonden" under contract 37671-1 "Next generation batteries" and the ALISTOREERI community at large, but especially the SIB brainstorms for many fruitful discussions. Furthermore, we wish to acknowledge Chalmers Master Card foundation for the travel and accommodation grants for KW. All calculations were carried out at the Wrocław Centre for Networking and Supercomputing (www.wcss.pl), grant no. 346. 


\section{Associated Content}

Supporting Information Available: Ionic conductivities, density and viscosity as a function of salt concentration and temeprature; Electrochemical data for $1 \mathrm{M} \mathrm{NaPF}_{6}$ in $\mathrm{EC}_{50}: \mathrm{DMC}_{50}$; Possible reaction pathways; FTIR spectra of cycled and pristine anode.

\section{References}

(1) Pan, H.; Hu, Y.-S.; Chen, L. Room-Temperature Stationary Sodium-Ion Batteries for Large-Scale Electric Energy Storage. Energy Environ. Sci. 2013, 6, 2338-2360.

(2) Armand, M.; Tarascon, J.-M. Building Better Batteries. Nature 2008, 451, 652-657.

(3) Bradley, D.; Jaskula, B. W. Lithium Statistics and Information Fact Sheet; Fact Sheet; USGS Numbered Series; U.S. Geological Survey: Reston, VA, 2014; p 2.

(4) Grosjean, C.; Miranda, P. H.; Perrin, M.; Poggi, P. Assessment of World Lithium Resources and Consequences of Their Geographic Distribution on the Expected Development of the Electric Vehicle Industry. Renew. Sustain. Energy Rev. 2012, 16, $1735-1744$.

(5) Kubota, K.; Komaba, S. Review-Practical Issues and Future Perspective for Na-lon Batteries. J. Electrochem. Soc. 2015, 162, A2538-A2550.

(6) Stauffer, P. H.; Hendley, J. W. Rare Earth Elements - Critical Resources for High Technology; Fact Sheet; USGS Numbered Series; U.S. Geological Survey: Reston, VA, $2002 ;$ p 2.

(7) Dugas, R.; Zhang, B.; Rozier, P.; Tarascon, J. M. Optimization of Na-Ion Battery Systems Based on Polyanionic or Layered Positive Electrodes and Carbon Anodes. J. Electrochem. Soc. 2016, 163, A867-A874. 
(8) Dahbi, M.; Yabuuchi, N.; Kubota, K.; Tokiwa, K.; Komaba, S. Negative Electrodes for Na-Ion Batteries. Phys. Chem. Chem. Phys. 2014, 16, 15007-15028.

(9) Ponrouch, A.; Goñi, A. R.; Palacín, M. R. High Capacity Hard Carbon Anodes for Sodium Ion Batteries in Additive Free Electrolyte. Electrochem. Commun. 2013, 27, 85-88.

(10) Zhang, B.; Dugas, R.; Rousse, G.; Rozier, P.; Abakumov, A. M.; Tarascon, J.-M. Insertion Compounds and Composites Made by Ball Milling for Advanced Sodium-Ion Batteries. Nat. Commun. 2016, 7, 10308.

(11) Park, Y.-U.; Seo, D.-H.; Kim, H.; Kim, J.; Lee, S.; Kim, B.; Kang, K. A Family of HighPerformance Cathode Materials for Na-Ion Batteries, Na3 (VO 1-x PO 4 ) 2 F 1+2 x $(0 \leq x \leq 1)$ : Combined First-Principles and Experimental Study. Adv. Funct. Mater. 2014, 24, 4603-4614.

(12) lermakova, D. I.; Dugas, R.; Palacín, M. R.; Ponrouch, A. On the Comparative Stability of Li and Na Metal Anode Interfaces in Conventional Alkyl Carbonate Electrolytes. J. Electrochem. Soc. 2015, 162, A7060-A7066.

(13) Moshkovich, M.; Gofer, Y.; Aurbach, D. Investigation of the Electrochemical Windows of Aprotic Alkali Metal (Li, Na, K) Salt Solutions. J. Electrochem. Soc. 2001, 148, E155E167.

(14) Eshetu, G. G.; Grugeon, S.; Kim, H.; Jeong, S.; Wu, L.; Gachot, G.; Laruelle, S.; Armand, M.; Passerini, S. Comprehensive Insights into the Reactivity of Electrolytes Based on Sodium lons. ChemSusChem 2016, 462-471.

(15) Jache, B.; Binder, J. O.; Abe, T.; Adelhelm, P. A Comparative Study on the Impact of Different Glymes and Its Derivatives as Electrolyte Solvents for Graphite Co- 
Intercalation Electrodes in Lithium-Ion and Sodium-Ion Batteries. Phys Chem Chem Phys 2016, 18, 14299-14316.

(16) Hasa, I.; Dou, X.; Buchholz, D.; Shao-Horn, Y.; Hassoun, J.; Passerini, S.; Scrosati, B. A Sodium-Ion Battery Exploiting Layered Oxide Cathode, Graphite Anode and GlymeBased Electrolyte. J. Power Sources 2016, 310, 26-31.

(17) Seh, Z. W.; Sun, J.; Sun, Y.; Cui, Y. A Highly Reversible Room-Temperature Sodium Metal Anode. ACS Cent. Sci. 2015, 1, 449-455.

(18) Zhu, Y.-E.; Yang, L.; Zhou, X.; Li, F.; Wei, J.; Zhou, Z. Boosting the Rate Capability of Hard Carbon with an Ether-Based Electrolyte for Sodium Ion Batteries. J. Mater. Chem. A 2017, 5, 9528-9532.

(19) Wang, C.; Wang, L.; Li, F.; Cheng, F.; Chen, J. Bulk Bismuth as a High-Capacity and Ultralong Cycle-Life Anode for Sodium-Ion Batteries by Coupling with Glyme-Based Electrolytes. Adv. Mater. 2017, 29, 1702212.

(20) Lei, K.; Wang, C.; Liu, L.; Luo, Y.; Mu, C.; Li, F.; Chen, J. A Porous Network of Bismuth Used as the Anode Material for High-Energy-Density Potassium-Ion Batteries. Angew. Chem. Int. Ed. 2018, 57, 4687-4691.

(21) Carbone, L.; Munoz, S.; Gobet, M.; Devany, M.; Greenbaum, S.; Hassoun, J. Characteristics of Glyme Electrolytes for Sodium Battery: Nuclear Magnetic Resonance and Electrochemical Study. Electrochimica Acta 2017, 231, 223-229.

(22) Tang, S.; Zhao, H. Glymes as Versatile Solvents for Chemical Reactions and Processes: From the Laboratory to Industry. RSC Adv. 2014, 4, 11251-11287.

(23) Aurbach, D.; Granot, E. The Study of Electrolyte Solutions Based on Solvents from the "Glyme" Family (Linear Polyethers) for Secondary Li Battery Systems. Electrochimica Acta $1997,42,697-718$. 
(24) Tobishima, S.; Morimoto, H.; Aoki, M.; Saito, Y.; Inose, T.; Fukumoto, T.; Kuryu, T. Glyme-Based Nonaqueous Electrolytes for Rechargeable Lithium Cells. Electrochimica Acta 2004, 49, 979-987.

(25) Jache, B.; Adelhelm, P. Use of Graphite as a Highly Reversible Electrode with Superior Cycle Life for Sodium-Ion Batteries by Making Use of Co-Intercalation Phenomena. Angew. Chem. Int. Ed. 2014, 53, 10169-10173.

(26) Palomares, V.; Casas-Cabanas, M.; Castillo-Martinez, E.; Han, M. H.; Rojo, T. Update on Na-Based Battery Materials. A Growing Research Path. Energy Env. Sci 2013, 6, 2312-2337.

(27) Saravanan, K.; Mason, C. W.; Rudola, A.; Wong, K. H.; Balaya, P. The First Report on Excellent Cycling Stability and Superior Rate Capability of Na 3 V 2 (PO 4 ) 3 for Sodium Ion Batteries. Adv. Energy Mater. 2013, 3, 444-450.

(28) Lepoivre, F.; Grimaud, A.; Larcher, D.; Tarascon, J.-M. Long-Time and Reliable Gas Monitoring in Li-O2 Batteries via a Swagelok Derived Electrochemical Cell. J. Electrochem. Soc. 2016, 163, A923-A929.

(29) Barone, V.; Cossi, M.; Tomasi, J. Geometry Optimization of Molecular Structures in Solution by the Polarizable Continuum Model. J. Comput. Chem. 1998, 19, 404-417.

(30) Zhao, Y.; Truhlar, D. G. The M06 Suite of Density Functionals for Main Group Thermochemistry, Thermochemical Kinetics, Noncovalent Interactions, Excited States, and Transition Elements: Two New Functionals and Systematic Testing of Four M06Class Functionals and 12 Other Functi. Theor. Chem. Acc. 2008, 120, 215-241.

(31) Frisch, M. J.; Trucks, G. W.; Schlegel, H. B.; Scuseria, G. E.; Robb, M. A.; Cheeseman, J. R.; Scalmani, G.; Barone, V.; Mennucci, B.; Petersson, G. A.; Nakatsuji, H.; Caricato, M.; Li, X.; Hratchian, H. P.; Izmaylov, A. F.; Bloino, J.; Zheng, G.; Sonnenberg, J. L.; Hada, 
M.; Ehara, M.; Toyota, K.; Fukuda, R.; Hasegawa, J.; Ishida, M.; Nakajima, T.; Honda, Y.; Kitao, O.; Nakai, H.; Vreven, T.; Montgomery Jr., J. A.; Peralta, J. E.; Ogliaro, F.;

Bearpark, M. J.; Heyd, J.; Brothers, E. N.; Kudin, K. N.; Staroverov, V. N.; Kobayashi, R.; Normand, J.; Raghavachari, K.; Rendell, A. P.; Burant, J. C.; Iyengar, S. S.; Tomasi, J.;

Cossi, M.; Rega, N.; Millam, N. J.; Klene, M.; Knox, J. E.; Cross, J. B.; Bakken, V.; Adamo, C.; Jaramillo, J.; Gomperts, R.; Stratmann, R. E.; Yazyev, O.; Austin, A. J.; Cammi, R.; Pomelli, C.; Ochterski, J. W.; Martin, R. L.; Morokuma, K.; Zakrzewski, V. G.; Voth, G. A.; Salvador, P.; Dannenberg, J. J.; Dapprich, S.; Daniels, A. D.; Farkas, Ö.; Foresman, J. B.; Ortiz, J. V.; Cioslowski, J.; Fox, D. J. Gaussian 09, Revision E.01; Gaussian, Inc.: Wallingford, CT, USA, 2009.

(32) Zhang, X.; Pugh, J. K.; Ross, P. N. Computation of Thermodynamic Oxidation Potentials of Organic Solvents Using Density Functional Theory. J. Electrochem. Soc. 2001, 148, E183.

(33) Trasatti, S. The Absolute Electrode Potential: An Explanatory Note. Pure Appl. Chem. 1986, 58, 955-966.

(34) Schmidt, M.; Heider, U.; Kuehner, A.; Oesten, R.; Jungnitz, M.; Ignat'ev, N.; Sartori, P. Lithium Fluoroalkylphosphates: A New Class of Conducting Salts for Electrolytes for High Energy Lithium-Ion Batteries. J. Power Sources 2001, 97, 557-560.

(35) Hefter, G. T.; Salomon, M. Conductivities of 1 ?1 Salts in 2-Cyanopyridine. J. Solut. Chem. 1994, 23, 579-593.

(36) Ponrouch, A.; Monti, D.; Boschin, A.; Steen, B.; Johansson, P.; Palacin, M. R. NonAqueous Electrolytes for Sodium-Ion Batteries. J Mater Chem A 2015, 3, 22-42.

(37) MacFarlane, D. R.; Forsyth, M.; Izgorodina, E. I.; Abbott, A. P.; Annat, G.; Fraser, K. On the Concept of Ionicity in Ionic Liquids. Phys Chem Chem Phys 2009, 11, 4962-4967. 
(38) Xu, W.; Cooper, E. I.; Austen Angell, C. Ionic Liquids: Ion Mobilities, Glass Temperatures, and Fragilities. J. Phys. Chem. B 2003, 107, 6170-6178.

(39) Austen Angell, C.; Ansari, Y.; Zhao, Z. Ionic Liquids: Past, Present and Future. Faraday Discuss 2012, 154, 9-27.

(40) Dugas, R.; Ponrouch, A.; Gachot, G.; David, R.; Palacin, M. R.; Tarascon, J. M. Na Reactivity toward Carbonate-Based Electrolytes: The Effect of FEC as Additive. J. Electrochem. Soc. 2016, 163, A2333-A2339.

(41) Ebnesajjad, S. Surface Treatment of Fluoropolymers for Adhesion. In Fluoroplastics: Volume 2, Melt processible fluoropolymers : the definitive user's guide and data book; Elsevier, 2015; pp 564-588.

(42) Palomares, V.; Serras, P.; Villaluenga, I.; Hueso, K. B.; Carretero-González, J.; Rojo, T. Na-lon Batteries, Recent Advances and Present Challenges to Become Low Cost Energy Storage Systems. Energy Environ. Sci. 2012, 5, 5884.

(43) Aurbach, D.; Daroux, M.; Faguy, P.; Yeager, E. The Electrochemistry of Noble Metal Electrodes in Aprotic Organic Solvents Containing Lithium Salts. J. Electroanal. Chem. Interfacial Electrochem. 1991, 297, 225-244.

(44) Bommier, C.; Surta, T. W.; Dolgos, M.; Ji, X. New Mechanistic Insights on Na-Ion Storage in Nongraphitizable Carbon. Nano Lett. 2015, 15, 5888-5892.

(45) Stevens, D. A.; Dahn, J. R. The Mechanisms of Lithium and Sodium Insertion in Carbon Materials. J. Electrochem. Soc. 2001, 148, A803.

(46) Stevens, D. A.; Dahn, J. R. High Capacity Anode Materials for Rechargeable SodiumIon Batteries. J. Electrochem. Soc. 2000, 147, 1271-1273.

(47) Verma, P.; Maire, P.; Novák, P. A Review of the Features and Analyses of the Solid Electrolyte Interphase in Li-Ion Batteries. Electrochimica Acta 2010, 55, 6332-6341. 
(48) Zhang, X.; Kostecki, R.; Richardson, T. J.; Pugh, J. K.; Ross, P. N. Electrochemical and Infrared Studies of the Reduction of Organic Carbonates. J. Electrochem. Soc. 2001, 148, A1341.

(49) Zhuang, G.; Ross, P. N. Contrasting Film Formation Reactions of Ethereal and Carbonate Solvents on Metallic Lithium. J. Power Sources 2000, 89, 143-148.

(50) Gachot, G.; Grugeon, S.; Armand, M.; Pilard, S.; Guenot, P.; Tarascon, J.-M.; Laruelle, S. Deciphering the Multi-Step Degradation Mechanisms of Carbonate-Based Electrolyte in Li Batteries. J. Power Sources 2008, 178, 409-421.

(51) Gachot, G.; Ribière, P.; Mathiron, D.; Grugeon, S.; Armand, M.; Leriche, J.-B.; Pilard, S.; Laruelle, S. Gas Chromatography/Mass Spectrometry As a Suitable Tool for the Li-lon Battery Electrolyte Degradation Mechanisms Study. Anal. Chem. 2011, 83, 478-485.

(52) Gachot, G.; Grugeon, S.; Jimenez-Gordon, I.; Eshetu, G. G.; Boyanov, S.; Lecocq, A.; Marlair, G.; Pilard, S.; Laruelle, S. Gas Chromatography/Fourier Transform Infrared/Mass Spectrometry Coupling: A Tool for Li-Ion Battery Safety Field Investigation. Anal Methods 2014, 6, 6120-6124.

(53) Memarzadeh Lotfabad, E.; Kalisvaart, P.; Kohandehghan, A.; Karpuzov, D.; Mitlin, D. Origin of Non-SEI Related Coulombic Efficiency Loss in Carbons Tested against $\mathrm{Na}$ and Li. J Mater Chem A 2014, 2, 19685-19695.

(54) Cabello, M.; Chyrka, T.; Klee, R.; Aragón, M. J.; Bai, X.; Lavela, P.; Vasylchenko, G. M.; Alcántara, R.; Tirado, J. L.; Ortiz, G. F. Treasure Na-Ion Anode from Trash Coke by Adept Electrolyte Selection. J. Power Sources 2017, 347 (Supplement C), 127-135. 


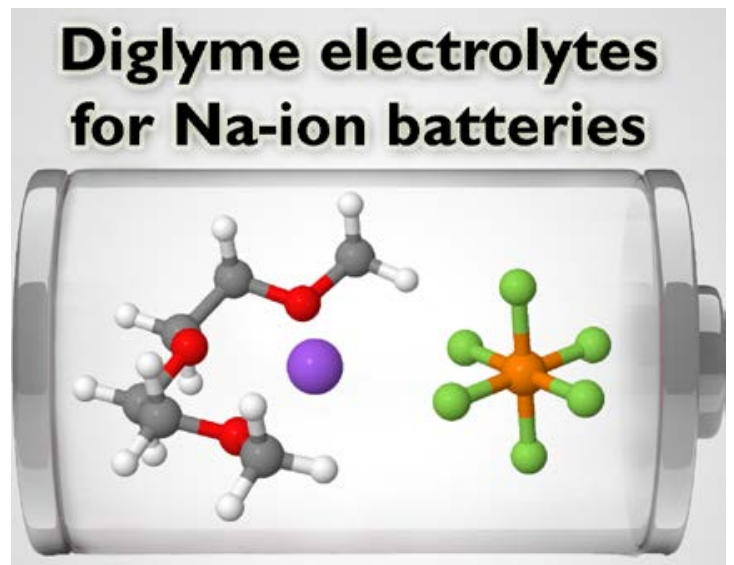

